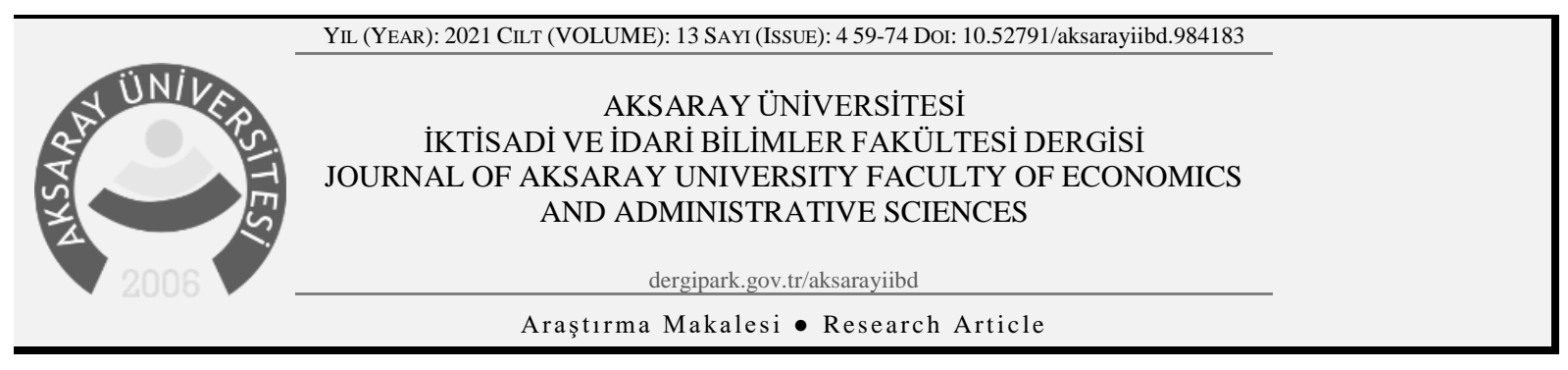

\title{
COVID-19’un Ekonomik Etkileri Üzerine Genel Bir İnceleme
}

\author{
An Overview of the Economic Impact of COVID-19
}

\author{
Ibrahim Bakurtaş ${ }^{1}$ ve Engin Can Ozan ${ }^{2}$ \\ ${ }^{1}$ Prof. Dr., Aksaray Üniversitesi, İktisadi ve İdari Bilimler Fakültesi, İktisat Bölümü, ibakirtas@aksaray.edu.tr, Orcid ID: 0000-0003-0945- \\ 2823 \\ ${ }^{2}$ Arş. Gör. Aksaray Üniversitesi, İktisadi ve İdari Bilimler Fakültesi, İktisat Bölümü, engincanozan@aksaray.edu.tr, Orcid ID: 0000-0002- \\ $7610-221 X$
}

M A K A L E B İ L G İ S İ

Anahtar Kelimeler

COVID-19,

Finansal Piyasalar,

Döviz Kuru,

Kamu Harcamalart

\section{Makale Geçmiși:}

Geliş Tarihi: 18 Ağustos 2021

Kabul Tarihi: 10 Kastm 2021

A R T I C L E I N F O

\section{Keywords}

COVID-19,

Financial Market,

Exchange Rate,

Government Expenditure

\section{Article History:}

Received: 18 August 2021

Accepted: 10 November 2021

\section{Ö ZET}

Bu makalenin amacı, koronavirüs (COVID-19) salgınının ekonomi üzerindeki etkisine ilişkin mevcut araştırmaların yöntemleri, bulguları ve politikalarıyla detaylı şekilde inceleyerek, genel bir değerlendirme sunmak ve bu etkileri en çok vak’a görülen ilk 10 ülkenin zaman serileri grafikleriyle göstermektir. Çalışma, hazırlanan literatür kapsamında salgının ekonomik etkilerini araştırmakta ve bu etkileri azaltmak için önerilen politika önerilerini tartışmaktadır. Hazırlanan literatür araştırmasına göre COVID19'a bağlı ölümlerin yanı sıra olumsuz emakroekonomik göstergeleri üzrinden konomik etkilerin de gözlemlendiği kanıtlamaktadır. Bu olumsuz ekonomik etkiler finansal piyasalar, döviz kuru, kamu harcamaları ve enerji fiyatları özelinde incelenmektedir. Bu incelemeler COVID-19 ile mücadelede kullanılacak politika önerilerinin daha iyi anlaşılmasına yönelik ipuçları vermektedir. Elde edilen sonuçlara göre ulusal ve uluslararası düzeylerde daha fazla politika koordinasyonu COVID-19'un olumsuz ekonomik etkilerini sınırlandırmaktadır.

\begin{abstract}
A B S T R A C T
The purpose of this article is to make a general assessment of the effects of the coronavirus (COVID-19) epidemic on national economies by examining in detail with the methods, findings and policies of current research, and to show these effects with time series graphs based on the 10 economies with the highest number of daily cases. The study explores the economic effects of the epidemic and discusses policy recommendations to mitigate these effects. According to the literature research prepared, it proves that negative economic effects are observed as well as deaths due to COVID-19. These negative economic effects are analyzed in terms of financial markets, exchange rates, public expenditures and energy prices. These reviews provide clues for a better understanding of policy recommendations to be used in the fight against COVID-19. According to the results, greater policy coordination at the national and international levels is limiting the negative economic effects of COVID-19.
\end{abstract}

$\mathrm{C}$ OVID-19 gibi bulaşıcılık oranı oldukça yüksek salgın hastalıklar dünya nüfusunun giderek şehirlerde yoğunlaşmasıyla birlikte ülkeler için ciddi sağlı ve ekonomik sorunlar yaratmaktadır. Sanayi Devrimi’nin başlangıcından itibaren küresel ekonomik gelişmenin de bir sonucu olarak insan nüfusu artış hızı yükselmiştir. İnsan nüfusunun hızlı artışı ve küresel ölçekte insan hareketliliğinin artması bulaşııı hastalıkların ortaya çıkmasını ve yayılmasını kolaylaştırmıştır.

Veba, Kolera ve COVID gibi bir salgın ülkelerin hem nüfusu hem de ekonomik performansı üzerinde yıkıcı sonuçlar doğurabilir. Örneğin, Birinci Dünya Savaşı'ndan sonra yaşanan 20. yüzyılın en büyük sağlık şoku olan 1918'deki İspanyol gribi dünya çapında 50 milyon insanın ölümüne sebep olmuştur. Ölümlere ek olarak, ekonomik ve sağlık krizlerini de beraberinde getirmiştir. Dahası, bir salgın toplumda sosyo-psikolojik ve sosyo-ekonomik sorunlara neden olabilir. Bu sorunlarla yoksullar zenginlere göre daha fazla muhatap olurken, krizin yükünü de yoksullar yüklenmektedir. Bilim adamları benzer salgınların her zaman tekrar edebileceği konusunda uyarılarda bulunmuştur. Bir salgın, özellikle ilaç ve aşı sektöründeki buluşların zaman alıcı özelliğiyle birleştiğinde toplumlar için büyük risk ve belirsizlik içermektedir. 2020 yılına gelindiğinde, COVID-19 virüsü 
küresel sağlık sistemini ve ekonomik faaliyetleri derinden sarsmış ve hükümetlere hastalık ve hastalığın ekonomik ve sosyal etkileri ile mücadelede aktif rol yüklemiştir. Her ne kadar İspanyol gribinden daha az ölümcül olsa da COVID-19 dünya çapında endişe verici sayıda ölümle sonuçlanan vakaya neden olmuştur.

Ekonomik faaliyetlerin doğasındaki gelişmeler ve artan karşılıklı iktisadi bağımlılıklar bulaşıcı hastalıkların yayılma hızını arttıırken, kontrol altına alınmasını yavaşlatmaktadır. Genişleyen pazarlar ve küreselleşmenin getirdiği ekonomik uzmanlaşma ve daha fazla iş bölümü olarak özetlenebilecek olan karşılıklı iktisadi bağımlılıklar COVID-19'un yayılım sürecinde de kendini göstermiştir. Modern ekonomilerde ekonomik faaliyetlerdeki bu yüksek bağımlılık göz önüne alındığında özellikle salgın hastalıkların ekonomik sonuçları küresel ve bölgesel anlamda ciddi maliyetlere neden olabilmektedir.

Devam eden COVID-19 salgınının ekonomik etkilerini daha iyi anlayabilmek için hikâyenin başlangıcına bakmakta fayda vardır. Aralık 2019'un başında Çin'in Hubei eyaletine bağlı Wuhan şehrinde ilk defa COVID-19 virüsü tespit edilmiştir. Hızla yayılarak çoğu ülkedeki bireyleri enfekte etmesi uzun sürmemiştir. Yaklaşık dört ay gibi kısa bir süre içerisinde bütün dünyaya yayılmıştır. 11 Mart 2020 tarihinde ise Dünya Sağlık Örgütü tarafından COVID-19 küresel bir salgın olarak ilan edilmiştir. Hem genç hem de yaşlı bireyleri öldürebildiği ve normal gripten daha fazla ölüm riskine (\%1) sahip olduğu için COVID-19 virüsü yüzyılın patojeni olarak kabul edilmiştir.

Bu patojenin yıkıcı etkileri ekonomileri de derinden etkilemiştir. COVID-19 virüsü ekonomi açısından ise gerçek anlamda negatif verimlilik şoku olarak tanımlanabilir. Böyle bir şokun ekonomi üzerindeki etkisi daraltıcı olmuştur. Maliszewska vd. (2020), salgının ekonomi üzerindeki daraltıcı etkisinin 4 kanaldan işlediğini ileri sürmektedir: (1) emek piyasası üzerinden; (2) uluslararası ticaret üzerinden; (3) uluslararası insan hareketliliği üzerinden ve (4) mal ve hizmet sektörü üzerinden. Daraltıcı etkinin işlediği birinci kanal istihdamdaki azalma, sermaye talebinin azalmasına ve dolayısıyla çıktı kaybına yol açmaktadır. İkincisi, mal ve hizmetler için ithalat ve ihracatın artan maliyetleri, ticaretin azalmasına ve ulusal verimlilik kaybına neden olur. Üçüncüsü, uluslararası turizmdeki keskin düşüş, daha az gelir yaratır ve dolayısıyla üretim kaybına yol açar. Son olarak, eskisinden daha az hizmet satın alan hanehalklarının talebindeki düşüş, mal ve hizmet tüketimini önemli ölçüde azaltır. Ayrıca doğrudan yabancı sermaye yatırımlarındaki daralma ve finansal şoklar da COVID-19'un ekonomik maliyetlerini daha da arttırmaktadır. COVID-19'un ekonomi üzerindeki bu doğrudan ve dolaylı etkileri araştırmacıların konuya olan ilgisini ve merakını önemli ölçüde etkilemiştir. Bu amaçla bu konu ile ilgili pek çok çalışma yapılmış ve politika önerileri sunulmuştur. Üzerinde yoğun çalışılan bu konu, belirli bir sistematik ile, özellikle bulguları bağlamında, Padhan ve Prabheesh (2021) tarafından genel bir değerlendirme metni içerisinde bir araya getirilerek özetlenmiş ve Economic Analysis and Policy'de yayımlanmıştır. Bu makale çalışmamızında da ilham kaynağıdır.

$\mathrm{Bu}$ çalışma bu temel ilham kaynağı veri alındığında genel bir değerlendirme özelliği taşımaktadır ve öne çıkan bazı makroekonomik göstergeler üzerinden tespitleri içermektedir. $\mathrm{Bu}$ güncelleştirmede seçilen dergiler ve raporlar aynen korunurken ülke örnekleminde Padhan ve Prabheesh (2021)'in benimsediği mantığa sadık kalınmıştır. Bu çalışma 54 makale üzerine inşa edilmiştir. Bu makaleler, Journal of Economic History, Applied Economic Letters, Asian Economic Letters, Economic Analysis and Policy, Emerging Markets Finance and Trade, Energy Economics, Energy Research Letters, Journal of Behavioral and Experimental Finance ve Finance Research Letters dergilerinde yayımlanmıştır. COVID-19 salgınıyla ilgili literatürün gelişmekte olduğu göz önünde bulundurularak, Padhan ve Prabheesh'in çalışmasının kapsadığı son tarih olan Eylül 2020 ile 1 Mayıs 2021 aralığında yayınlanan makalelerin genel değerlendirmesi yapılmıştır. Bu makaleler COVID-19'un ekonomi üzerindeki etkilerinin farklı yönlerini kapsamaktadır. Bu doğrultuda, 1 Mayıs 2021'e kadar en çok vaka görülen 10 ekonomi olarak belirlenmiştir. Bu ekonomilerin COVID-19 öncesi ve COVID-19 dönemlerinde borsa göstergeleri ve döviz kuru performansları ülke seçimindeki mantığa sadık kalınarak güncellenmiştir.

Bu makale COVID-19 olarak isimlendirilen yüzyılın salgını olarak kabul edilmiş bir virüsün ekonomiler üzerindeki etkilerini incelemiş olan araştırmaların bulguları üzerine inşa edilmiştir. Başladığı günden bugüne COVID-19'un etkilerini inceleyen araştırmaların sayısı her geçen gün hızla artmaktadır. Bu nedenle, bu çalışma literatürün daha etkili kullanılmasında yardımcı olacaktır. Bu araştırmanın şekillenmesinde COVID-19'un ekonomi üzerindeki etkilerini inceleyen ve çözüm önerileri sunan araştırmaları bir araya getiren Padhan ve Prabheesh (2021) özel bir yere sahiptir. Bu bağlamda çalışma, COVID-19'un ekonomi üzerindeki etkilerini inceleyen ve bu etkilerin büyüklüğünün azaltılmasına yönelik politika önerilerini tartışan çalışmaların bulgularını ve çözüm önerilerini belirli bir sistematik içinde sunmayı amaçlamaktadır.

Bu makale sırasıyla şu şekilde düzenlenmiştir. Giriş bölümüne takip eden birinci bölümde COVID-19'un ekonomik etkileri incelenirken; ikinci bölümde COVID-19 ile ilgili ampirik literatüre yer verilmiştir. Üçüncü ve dördüncü bölümde COVID19'un finans piyasaları ve döviz kuru ile ilişkisi incelenmiştir. Beşinci bölümde COVID-19 ile mücadelede hükümet müdahalelerinin ve kamu harcamalarının etkisi tartışılmıştır. Altıncı bölümde COVID-19'un enerji ve petrol piyasası ile ilişkisi incelenmiştir. Yedinci bölümde politika önerileri sunulmuştur. Sekizinci bölümde sonuç ve değerlendirmelere yer verilmiştir. 


\section{COVID-19'UN EKONOMIKK ETKIILERI}

Aralık 2019 tarihinden itibaren tüm dünyada yankı uyandıran ve birçok ölüme sebep olan koranavirüs hızla yayılmaya devam etmektedir. Tüm dünyayı alarma geçiren bu virüs ile mücadelede tedavi arayışları virüsün sürekli mutasyona uğraması sebebiyle zorlaşmaktadır. Bu süreçte virüs ile mücadelede en iyi yol bilinçlendirme ve yaşamı buna göre şekilledirmekten geçtiği gözlemlenmektedir. Devam eden aşılama işlemleri ve yeni aşı çalışmaları ile beraber virüsün ne olduğuna dair bilgi edinilmesi ve çıkış hikayesi virüs ile mücadelede önemli bir rol oynamaktadır.

COVID-19, koronavirüs ailesinden bir virüs çeşididir. 2020 y1lına kadar pek tehlike teşkil etmeyen koronavirüs yeni türüyle birçok ölüme sebep olmaktadır. COVID-19'a kadar bu virüs ailesinden toplam ölüm vakası 3 iken bu sayı 2020 yılı itibariyle hızla yükselmektedir. Hastalık kendini solunum yolu hastalı̆̆ belirtileri ile ortaya çıkarmaktadır. Bu belirtiler kuluçka süresi olan 2 ile 14 gün arasında hissettirmektedir.

Koronavirüsün bu türüne ilk defa Aralık 2019 tarihinde Çin'in Wuhan kentinde rastlanmıştır. Seyahat yoluyla hızla dünya geneline yayılmıştır. COVID-19 ölümlere sebep olmasının yanında ciddi ekonomik sorunlara da sebep olmuştur. COVID-19 salgınının yayılması, dünyadaki kapanmalar ve ekonomik faaliyetlerin benzeri görülmemiş ölçüde kesintiye uğraması nedeniyle çok çeşitli ekonomik zararlar bırakmaktadır. Gelişmiş ve gelişmekte olan ülkelerde yoğunlaşan salgın, ekonomik aktivitelerde olağanüstü bir hız ve ölçekte kesintilere yol açmaktadır. Ülkeler virüsün yayılmasını engellemek amacıyla ulaşım imkanlarını sınırlandırmış olsalar da ekonominin küreselleşmesi yayılım hızını arttıran bir faktör olarak ortaya çıkmaktadır. Ekonomik faaliyetlerin bir anda durdurulamaması COVID-19'un hızla tüm dünyada etkisini göstermesine neden olmaktadır. Ancak COVID-19 ile mücadelede yapılan müdahaleler ekonomik faaliyetlerdeki etkisini hızla göstermektedir.

COVID-19 salgınının halen devam ediyor olması ekonomik etkilerinin tam olarak keşfedilmesini engellemektedir. Ancak salgının dünya genelinde hızla yayılması hem arz hem talep yönünde belirleyici olan ülkelerin makroekonomik göstergelerini ve küresel makroekonomik değişkenleri olumsuz etkileyecektir. Örneğin, küresel GSYİH, ekonomik bozulma nedeniyle 2020'nin ikinci çeyreğinde \%4,9'dan fazla azalmıştır. Mal ve hizmet ticaretindeki düşüş muhtemelen 2008 küresel mali krizindekinden daha yüksek gerçekleşecektir. Sonuç olarak, küresel ticaret 2020'nin ikinci çeyreğinde zayıf talep ve arz nedeniyle\%3,5 daralmıştır. COVID-19 ile mücadelede uygulanan kilitlenme ve kapanmalar küresel tedarik zincirlerini bozarak toplam talepte olumsuz bir etki yaratmaktadır (Qin vd., 2020). Hanehalkı gelirlerindeki yüksek kayıp ve tüketici güvenindeki zayıflamalar nedeniyle mal ve hizmet tüketimi belirgin şekilde bir düşüş ile karşılaşmaktadır.

Tüketiciler COVID-19'a yakalanma korkusu nedeniyle belirli mal ve hizmetleri tüketme konusunda daha isteksiz davranmaya başlamıştır. Dolayısıyla firmalar, talepteki bu ani düşüşler, arz kesintileri ve gelecekteki belirsiz kazançlar nedeniyle yatırımlarını azaltma konusunda daha istekli hale gelmişlerdir. Dünya çapında, 2020'nin ilk çeyreğindeki 130 tam zamanlı iş kaybından 2020'nin ikinci çeyreğinde yaklaşık 300 milyon tam zamanlı iş kaybedilmiştir (IMF, 2020).

Gelişmekte olan ekonomiler, salgın nedeniyle önemli sermaye çıkışları yaşamış, dolayısıyla yatırımları azaltmış ve üretim kaybına neden olmuştur (BIS, 2019). COVID-19 döneminde, Rusya-Suudi Arabistan petrol savaşı, petrol fiyatlarının değerini 8 Mart 2020'de varil başına 31.05 \$ 'dan 30 Nisan 2020'de varil başına 19.23 \$' a düşürdü. Benzer şekilde, dünya genelinde borsalar Şubat'tan itibaren çökmeye başlamıştır. Örneğin Wall Street, ABD'nin seyahat yasağı ilanından sonra yatırımcı güveninin olmaması ve Avrupa merkez bankasının faiz oranının değişmemesi nedeniyle Mart 2020'nin ikinci haftasında hisse senedi fiyatında tek günlük büyük bir düşüşe tanık oldu. Sonuç olarak, devam eden salgın küresel ekonomiyi olumsuz etkilemekte; artan ölümler ve sürekli mutasyona uğrayan virüsün ekonomilerde etkisinin de devam edeceği aşikardır.

\section{COVID-19 İLE İLGILİ AMPIRİK LITERATÜR}

COVID-19'un ekonomik etkileri Tablo 1'de detaylı literatür özeti olarak sunulmaktadır. Literatür taraması sadece ampirik çalışmaları içermektedir. Bu tabloda yazar(lar)a, araştırma sorusuna, örnekleme, yönteme ve ampirik bulgulara ve değerlendirmelere yer verilmektedir. Tablodaki satırlar yazarların soyadlarının alfabetik sıralamasına göredir. 
Tablo 1: COVID-19'un Ekonomik Etkileri Ampirik Literatür

\begin{tabular}{|c|c|c|c|c|}
\hline Yazar(lar) & Araștırma Sorusu & Örneklem/Zaman Dilimi & Yöntem & Ampirik Bulgular ve Değerlendirme \\
\hline $\begin{array}{l}\text { Akhtaruzzaman, } \\
\text { M., vd. (2021) }\end{array}$ & $\begin{array}{l}\text { COVID-19 döneminde Çin ve G7 } \\
\text { ülkeleri arasındaki finansal bulaşma } \\
\text { etkisi nasıl gerçekleşmiştir? }\end{array}$ & $\begin{array}{l}\text { Çin ve G7 Ülkeleri, } 1 \text { Ocak } \\
\text { 2013-30 Aralık } 2019 \text { ve } 31 \\
\text { Aralık 2019-20 Mart } 2020\end{array}$ & $\begin{array}{l}\text { GARCH } \\
\text { analizi }\end{array}$ & $\begin{array}{l}\text { Finansal ve finansal olmayan firmaların hisse senedi getirileri arasındaki koşullu } \\
\text { korelasyonlarda artış yaşanmış̧ır. COVID-19 salgını sırasında bu korelasyonlardaki } \\
\text { artışın büyüklüğ̈ü finansal bulaşıcılığı arttırmaktadır. }\end{array}$ \\
\hline $\begin{array}{l}\text { Albulescu, C. T. } \\
\text { (2021) }\end{array}$ & $\begin{array}{l}\text { COVID-19 vakaları ve ölüm oranlarının } \\
\text { finansal piyasa oynaklığı üzerinde etkisi } \\
\text { var mıdır? }\end{array}$ & $\begin{array}{l}\text { ABD-11 Mart 2020-15 } \\
\text { Mayis } 2020\end{array}$ & OLS yöntemi & $\begin{array}{l}\text { Pozitif etkisi vardır. COVID-19 salgınının sürekliliği ve buna bağlı belirsizliğin ABD } \\
\text { finans piyasalarının oynaklığını artırdığının ve dolayısıyla küresel finansal döngüyü } \\
\text { etkilediği tespit edilmiştir. }\end{array}$ \\
\hline $\begin{array}{l}\text { Alexakis, C., } \\
\text { vd. }(2021)\end{array}$ & $\begin{array}{l}\text { COVID-19 ile mücadelede sosyal } \\
\text { uzaklaşma önlemlerinin analize konu } \\
\text { olan } 45 \text { borsa endeksi üzerine etkisi } \\
\text { hangi yönde gerçekleșmiștir? }\end{array}$ & 2 Ocak 2020-8 Nisan 2020 & $\begin{array}{l}\text { Dinamik } \\
\text { Mekansal } \\
\text { Durbin analizi }\end{array}$ & $\begin{array}{l}\text { Negatif yönde bir etki gerçekleşmiştir. Borsa getirilerinin ve kapanmaların yoğunluğu } \\
\text { olumsuz yönde ilişkilidir. }\end{array}$ \\
\hline $\begin{array}{l}\text { Amar, A. B., } \\
\text { vd. }(2021)\end{array}$ & $\begin{array}{l}\text { COVID-19 döneminde başlica petrol } \\
\text { üreten ve tüketen ülkelerdeki emtia ve } \\
\text { hisse senedi fiyatları arasındaki ilişki } \\
\text { nasıldır? }\end{array}$ & $\begin{array}{l}4 \text { Ocak 2010- } 6 \text { Mayis } \\
2020\end{array}$ & $\begin{array}{l}\text { Dalgacik } \\
\text { analizi }\end{array}$ & $\begin{array}{l}\text { Önemli bir karşılıklı bağımlılık mevcuttur. Mevcut sonuçların sağlamlığını kontrol } \\
\text { etmek için çalışmanın daha uzun bir gözlem periyoduna genişletilmesi } \\
\text { gerekmektedir. }\end{array}$ \\
\hline $\begin{array}{l}\text { Ashraf, B. N. } \\
(2020)\end{array}$ & $\begin{array}{l}\text { Hükümet politikalarının borsa getirileri } \\
\text { üzerindeki etkisi hangi yönde } \\
\text { gerçekleşmiştir? }\end{array}$ & $\begin{array}{l}77 \text { Ülke, } 22 \text { Ocak 2020-17 } \\
\text { Nisan } 2020\end{array}$ & OLS analizi & $\begin{array}{l}\text { COVID-19'a ilişkin sosyal mesafe önlemleri ekonomik faaliyetler üzerinde doğrudan } \\
\text { olumsuz; dolaylı olumlu etki yapmaktadır. Kamuoyu bilinçlendirme ve destek } \\
\text { programları olumlu piyasa getirileriyle sonuçlanmaktadır. }\end{array}$ \\
\hline $\begin{array}{l}\text { Azimli, A. } \\
(2020)\end{array}$ & $\begin{array}{l}\text { COVID-19 risk-getiri bağımlılığının } \\
\text { derecesini ve yapısını nasıl } \\
\text { etkilemektedir? }\end{array}$ & $\mathrm{ABD}$ & $\begin{array}{l}\text { Niceliksel } \\
\text { regresyon } \\
\text { analizi }\end{array}$ & $\begin{array}{l}\text { Bulgular; COVID-19’un risk getiri bağımlılı̆̆ının ve yapısını değiştirdiğini } \\
\text { göstermektedir. }\end{array}$ \\
\hline $\begin{array}{l}\text { Baek, S., vd. } \\
(2020)\end{array}$ & $\begin{array}{l}\text { COVID-19'un ABD borsa oynaklı̆̆ } 1 \\
\text { üzerindeki etkisi endüstri düzeyinde } \\
\text { nasıl gerçekleşmiştir? }\end{array}$ & $\begin{array}{l}\text { ABD, } 2 \text { Ocak 2020-30 } \\
\text { Nisan } 2020\end{array}$ & $\begin{array}{l}\text { Markow } \\
\text { değiştirme AR } \\
\text { modeli }\end{array}$ & $\begin{array}{l}\text { Bulgular oynaklığın belirli ekonomik göstergelerden etkilendiğini ve COVID-19 } \\
\text { vaka say1larına duyarlı olduğunu göstermektedir. Ayrıca tüm sektörlerdeki toplam ve } \\
\text { özel riskte önemli artışlar gözlenirken, sistematik riskteki değişiklikler endüstriye } \\
\text { göre farklılık göstermektedir. }\end{array}$ \\
\hline $\begin{array}{l}\text { Baig, A. S., vd. } \\
(2021)\end{array}$ & $\begin{array}{l}\text { COVID-19'un ABD hisse senedi } \\
\text { piyasalarının mikro yapısı üzerinde } \\
\text { etkisi var mıdır? }\end{array}$ & $\begin{array}{l}\text { ABD, } 13 \text { Ocak 2020-17 } \\
\text { Nisan } 2020\end{array}$ & OLS yöntemi & $\begin{array}{l}\text { COVID-19'un hisse senedi piyasalarının mikro yapısı üzerinde etkisi vardır. Ayrıca } \\
\text { COVID-19'a bağlı ölümlerde ve vak'a sayılarındaki artışlar piyasadaki likitide ve } \\
\text { oynaklıktaki artışla ilişsilidir. }\end{array}$ \\
\hline $\begin{array}{l}\text { Bal, D., ve } \\
\text { Mohanty, S. } \\
\text { (2021) }\end{array}$ & $\begin{array}{l}\text { COVID-19 ile borsa oynaklığı arasında } \\
\text { Granger nedenselliği var mıdır? }\end{array}$ & $\begin{array}{l}\text { Hindistan, } 3 \text { Mart 2020-8 } \\
\text { Ekim } 2020\end{array}$ & $\begin{array}{l}\text { Granger } \\
\text { Nedensellik } \\
\text { analizi }\end{array}$ & $\begin{array}{l}\text { COVID-19 ile borsa oynaklığı arasında Granger nedenselliği gözlemlenmiştir. Bu } \\
\text { bulgular COVID-19 vakalarını ve borsayı tahmin etmekte önemli bir role sahiptir. }\end{array}$ \\
\hline $\begin{array}{l}\text { Barrafrem, K., } \\
\text { vd. (2020) }\end{array}$ & $\begin{array}{l}\text { Gelecekteki finansal durum } \\
\text { beklentilerinin, devam eden bir salgın ve } \\
\text { ekonomik kriz sırasında finansal refahla } \\
\text { bağlantısı nasıl gerçekleşmektedir? }\end{array}$ & $\begin{array}{l}\text { Birleşik Krallık ve İsveç, } \\
\text { (18-20) Mart 2020-(7-23) } \\
\text { Nisan } 2020\end{array}$ & $\begin{array}{l}\text { Anket, } \\
\text { karşılaştırmalı } \\
\text { çalışma }\end{array}$ & $\begin{array}{l}\text { Bireyler geleceğin ekonomik görünümü konusunda çok kötümser durumdadırlar. } \\
\text { Ancak bir bütün olarak ulusal ve küresel ekonomiye kıyasla kendi ekonomik } \\
\text { durumları hakkında daha az karamsarlardır. }\end{array}$ \\
\hline Bing, T. (2021) & $\begin{array}{l}\text { COVID-19 döneminde perakende } \\
\text { yatırımcıların nakit akışları ve getirileri } \\
\text { arasında ilişki var mıdır? }\end{array}$ & $\begin{array}{l}\text { Çin, } 1 \text { Ocak 2019-31 Mart } \\
2020\end{array}$ & VAR analizi & $\begin{array}{l}\text { COVID-19 sırasında perakende yatırımcıların nakit akışları ve getirileri arasında bir } \\
\text { ilişki vardır. Bu durumun panik ticareti olduğu savunulmaktadır. }\end{array}$ \\
\hline $\begin{array}{l}\text { Cepoi, C. O. } \\
(2020)\end{array}$ & $\begin{array}{l}\text { COVID-19'dan en çok etkilenen } 6 \\
\text { ülkede borsa COVID-19 haberlerine ve } \\
\text { duyurularına nasil tepki vermiştir? }\end{array}$ & $\begin{array}{l}6 \text { Hisse Senedi Endeksi, } 3 \\
\text { Şubat 2020-17 Nisan } 2020\end{array}$ & $\begin{array}{l}\text { Panel } \\
\text { niceliksel } \\
\text { regresyon }\end{array}$ & $\begin{array}{l}\text { Bulgular medyanın kapsamı, orta ve üstün miktarlarda getirilerde bir azalmaya neden } \\
\text { olduğunu ve daha düşük olanlar üzerinde hiçbir etkisi olmadığını göstermektedir. } \\
\text { COVID-19 ile ilgili finansal kargaşayı azaltmak için uygun iletişim kanallarının daha } \\
\text { yoğun kullanımına ihtiyaç olduğu belirtilmektedir. }\end{array}$ \\
\hline $\begin{array}{l}\text { Chang Zhao, } \\
\text { Ziwei Liu ve } \\
\text { Yibing } \\
\text { Ding (2020) }\end{array}$ & $\begin{array}{l}\text { COVID-19'un Çin'in ekonomi politika } \\
\text { belirsizliği üzerinde bir etkisi var mıdır? }\end{array}$ & Çin, 2012Q1-2020Q3 & $\begin{array}{l}\text { Regresyon } \\
\text { analizi }\end{array}$ & $\begin{array}{l}\text { Negatif bir etkisi vardır. COVID-19 kaynaklı ekonomi politikaları belirsizliği } \\
\text { doğrudan dış yatırımların yoğun marjı üzerinde önemli bir etkiye sahip değildir. }\end{array}$ \\
\hline
\end{tabular}


Tablo 1 (Devamı): COVID-19'un Ekonomik Etkileri Ampirik Literatür

\begin{tabular}{|c|c|c|c|c|}
\hline Yazar(lar) & Araştırma Sorusu & Örneklem/Zaman Dilimi & Yöntem & Ampirik Bulgular ve Değerlendirme \\
\hline $\begin{array}{l}\text { Chiah, M., ve } \\
\text { Zhong, A. } \\
\text { (2020) }\end{array}$ & $\begin{array}{l}\text { COVID-19 dünya borsalarının işlem } \\
\text { hacmini nasıl etkilemiştir? }\end{array}$ & $\begin{array}{l}37 \text { Hisse Senedi Piyasas1, } 2 \\
\text { Ocak 2019- } 15 \text { Mayıs } 2020\end{array}$ & OLS yöntemi & $\begin{array}{l}\text { Ticaret hacmindeki artışın, her bir ülkenin ulusal kültürü ve kurumsal çevresi ile } \\
\text { ilişsili olduğu gözlemlenmiştir. Ayrıca yatırımcılar daha yüksek düzeyde güven ve } \\
\text { bireysellik ile daha düşük düzeyde belirsizlikten kaçınma ile karakterize edilen } \\
\text { toplumlarda daha yoğun ticaret yapma eğilimindedir. }\end{array}$ \\
\hline Ciner, C. (2021) & $\begin{array}{l}\text { COVID-19 döneminde ABD hisse } \\
\text { senedi getirileri öngürülebilir midir? }\end{array}$ & $\begin{array}{l}\text { ABD, } 2 \text { Ocak 2020-16 } \\
\text { Nisan } 2020\end{array}$ & $\begin{array}{l}\text { Lasso } \\
\text { öngürücü } \\
\text { regresyon } \\
\text { analizi }\end{array}$ & $\begin{array}{l}\text { Hem yatırım derecesi hem de yüksek getirili şirket tahvilleri, bu dönemde ABD hisse } \\
\text { senedi getirilerinin önemli belirleyicileridir. }\end{array}$ \\
\hline $\begin{array}{l}\text { Engelhardt, N., } \\
\text { vd. (2021) }\end{array}$ & $\begin{array}{l}\text { COVID-19 döneminde güvenin küresel } \\
\text { borsa oynaklı̆̆ üzerindeki etkisi hangi } \\
\text { yönde gerçekleşmiştir? }\end{array}$ & $\begin{array}{l}47 \text { Hisse Senedi Piyasas1, } \\
22 \text { Ocak 2020-29 Temmuz } \\
2020\end{array}$ & $\begin{array}{l}\text { Panel } \\
\text { regresyon }\end{array}$ & $\begin{array}{l}\text { COVID-19 vakası duyurularına tepki olarak borsaların oynaklı̆̆ının yüksek güvene } \\
\text { sahip ülkelerde önemli ölçüde daha düşük olduğu sonucuna ulaşılmıştır. Salgın } \\
\text { sırasında bir hükümetin eylemlerine olan güvenin yanı sıra, hükümetin emirlerine } \\
\text { uyan yurttaşlara duyulan güvenin de yatırımcılar arasındaki belirsizliği önemli ölçüde } \\
\text { azaltması beklenmektedir. }\end{array}$ \\
\hline $\begin{array}{l}\text { Espinosa- } \\
\text { Méndez, C., ve } \\
\text { Arias, J. (2021) }\end{array}$ & $\begin{array}{l}\text { COVID-19'un Avrupa'daki sürü } \\
\text { davranışları üzerindeki etkisi hangi } \\
\text { yönde değişiklik göstermiştir? }\end{array}$ & $\begin{array}{l}5 \text { Ülke, } 3 \text { Ocak 2000-19 } \\
\text { Haziran } 2020\end{array}$ & CSAD & $\begin{array}{l}\text { Pozitif yönde etkilemiştir. COVID-19 salgını Avrupa sermaye piyasalarında sürü } \\
\text { davranışııı arttırmaktadır. Ayrıca korku ve belirsizlik, daha az bilgili ajanları daha } \\
\text { bilgili olanları takip etmeye itecektir. }\end{array}$ \\
\hline $\begin{array}{l}\text { Fang, X. ve } \\
\text { Cao, W. (2021) }\end{array}$ & $\begin{array}{l}\text { COVID-19'un bir çapa para birimi } \\
\text { olarak RMB üzerinde etkisi var mıdır? }\end{array}$ & 40 Ülke & $\begin{array}{l}\text { Regresyon } \\
\text { analizi } \\
\text { Parametrik }\end{array}$ & $\begin{array}{l}\text { Negatif bir etkisi vardır. Ancak dünyanın Çin’e olan güveni arttıkça bu olumsuz } \\
\text { etkinin azalması beklenmektedir. }\end{array}$ \\
\hline $\begin{array}{l}\text { Fasanya, I. O. } \\
\text { vd. (2021) }\end{array}$ & $\begin{array}{l}\text { COVID-19'a dayalı enerji hisse senedi } \\
\text { piyasalarını tahmin etmede belirsizlik } \\
\text { var mıdır? }\end{array}$ & $\begin{array}{l}10 \text { Asya-Pasifik ülkesi, } 1 \\
\text { Ocak 2004-31 Ağustos } \\
2020\end{array}$ & $\begin{array}{l}\text { olmayan } \\
\text { Granger- } \\
\text { kuantil } \\
\text { nedensellik } \\
\text { analizi }\end{array}$ & $\begin{array}{l}\text { COVID-19'dan kaynaklanan doğrusal olmayan bir nedensel ilişki vardır. Bu durum } \\
\text { enerji pazarının COVID-19'a karşı savunmasızlığını desteklemektedir. }\end{array}$ \\
\hline $\begin{array}{l}\text { Feng, G. F., vd. } \\
(2021)\end{array}$ & $\begin{array}{l}\text { COVID-19 ile mücadelede hükümet } \\
\text { müdahalelerinin döviz kuru oynaklığı } \\
\text { üzerinde etkisi var mıdır? }\end{array}$ & $\begin{array}{l}20 \text { Ülke, } 13 \text { Ocak 2020-21 } \\
\text { Temmuz } 2020\end{array}$ & GMM analizi & $\begin{array}{l}\text { Pozitif yönde bir etki meydana getirmiştir. Teyit edilmiş vakalardaki artış döviz kuru } \\
\text { oynaklı̆̆ını önemli ölçüde arttırmıştır. Ancak okulların kapatılması, iç hareketlere } \\
\text { getirilen kısıtlamalar ve halkı bilgilendirme kampanyaları gibi çeşitli politikalar döviz } \\
\text { kuru oynaklığını engellemiştir. }\end{array}$ \\
\hline $\begin{array}{l}\text { Fernandez- } \\
\text { Perez, A., vd. } \\
\text { (2021) }\end{array}$ & $\begin{array}{l}\text { COVID-19 pandemisine ulusal kültürün } \\
\text { borsa tepkisi hangi yönde } \\
\text { gerçekleşmiştir? }\end{array}$ & 63 Ülke & $\begin{array}{l}\text { Regresyon } \\
\text { analizi }\end{array}$ & $\begin{array}{l}\text { İlk enfekte vaka duyurusundan sonraki ilk } 3 \text { hafta boyunca negatif getiri } \\
\text { gerçekleşmiştir. Ayrıca borsa tepkilerinin büyüklüğü bir ülkenin kültürel değerlerine } \\
\text { bağlıdır, bulgusu elde edilmiştir. }\end{array}$ \\
\hline $\begin{array}{l}\text { Fu, Q., ve } \\
\text { Chang, C.-P. } \\
\text { (2021) }\end{array}$ & $\begin{array}{l}\text { Salgınlar, devlet harcamaları ve kamu } \\
\text { sağlık harcamalarını etkiler mi? }\end{array}$ & 14 Ülke, 2000-2018 & $\begin{array}{l}\text { Panel sabit etki } \\
\text { modeli }\end{array}$ & $\begin{array}{l}\text { Salgınlar kamu harcamalarını ve sağlık harcamalarını pozitif yönde etkilemektedir. } \\
\text { Ancak toplam devlet harcamaları üzerinde anlamlı bir etkisi bulunmamaktadır. }\end{array}$ \\
\hline $\begin{array}{l}\text { Gharib, C., vd. } \\
\text { (2021) }\end{array}$ & $\begin{array}{l}\text { COVID-19'un ham petrol ve spot altın } \\
\text { fiyatlarına etkisi hangi yönde } \\
\text { gerçekleşmiştir ve aralarındaki Granger } \\
\text { nedesellik ilişkisi nasıl oluşmuştur? }\end{array}$ & 4 Ocak 2010-4 Mayıs 2020 & $\begin{array}{l}\text { Granger } \\
\text { nedensellik }\end{array}$ & $\begin{array}{l}\text { Negatif yönde bir etki vardır. Ayrıca COVID-19 salgını sırasında petrol ve altın } \\
\text { piyasalarında balonların iki taraflı bulaşma etkisi vardır }\end{array}$ \\
\hline $\begin{array}{l}\text { Gil-Alana, L. } \\
\text { A., ve Monge, } \\
\text { M. (2020) }\end{array}$ & $\begin{array}{l}\text { COVID-19 ham petrol fiyatlarını } \\
\text { etkilemiş midir? }\end{array}$ & $\begin{array}{l}4 \text { Mayıs 2010-4 Mayis } \\
2020\end{array}$ & $\begin{array}{l}\text { Kesirli } \\
\text { entegrasyon } \\
\text { analizi }\end{array}$ & $\begin{array}{l}\text { Pozitif yönde etkilemiştir. Ancak petrol fiyatlarına yönelik oluşan bu şoklar uzun } \\
\text { süreli de olsa geçicidir. }\end{array}$ \\
\hline
\end{tabular}


Tablo 1 (Devamı): COVID-19'un Ekonomik Etkileri Ampirik Literatür

\begin{tabular}{|c|c|c|c|c|}
\hline Yazar(lar) & Araştırma Sorusu & Örneklem/Zaman Dilimi & Yöntem & Ampirik Bulgular ve Değerlendirme \\
\hline $\begin{array}{l}\text { Goodell, J. W., } \\
\text { ve Goutte, S. } \\
\text { (2021) }\end{array}$ & $\begin{array}{l}\text { COVID-19 ve Bitcoin fiyatları arasında } \\
\text { ilişki var mıdır? }\end{array}$ & $\begin{array}{l}31 \text { Aralık 2019-29 Nisan } \\
2020\end{array}$ & $\begin{array}{l}\text { Dalgacık } \\
\text { tutarlılığ } 1 \\
\text { analizi }\end{array}$ & $\begin{array}{l}5 \text { Nisan sonrası dönemde, COVID-19 seviyelerinin Bitcoin fiyatlarında bir artışa } \\
\text { neden olduğu gözlemlenmiştir. }\end{array}$ \\
\hline $\begin{array}{l}\text { Goswami, B., } \\
\text { vd. (2021) }\end{array}$ & $\begin{array}{l}\text { COVID-19 makroekonomik performans } \\
\text { üzerinde bir etki meydana getirmiş } \\
\text { midir? }\end{array}$ & $\begin{array}{l}\text { Hindistan, Nisan 2020- } \\
\text { Kasım } 2020\end{array}$ & $\begin{array}{l}\text { Panel } \\
\text { regresyon } \\
\text { analizi } \\
\text { Sabit etki }\end{array}$ & $\begin{array}{l}\text { Negatif yönde bir etki meydana getirmiştir. Birincil sektörün nispeten daha büyük } \\
\text { istihdam payına sahip olduğu eyaletler daha küçük ekonomik kayıplar yaşamıştır. }\end{array}$ \\
\hline $\begin{array}{l}\text { Han, H. ve } \\
\text { Qian, Y. (2020) }\end{array}$ & $\begin{array}{l}\text { COVID-19 işletmelerin inovasyon } \\
\text { yeteneklerini hangi yönde etkilemiştir? }\end{array}$ & Çin, 2019Q1-2020Q2 & $\begin{array}{l}\text { modeli ve } \\
\text { panel veri } \\
\text { analizi }\end{array}$ & Pozitif etkilemiştir. Bu dönemde AR-GE yatırımları önemli ölçüde artmıştır. \\
\hline $\begin{array}{l}\text { Jena, P. R., vd. } \\
(2021) \text {. }\end{array}$ & $\begin{array}{l}\text { COVID-19'un GSYH üzerinde etkisi } \\
\text { var mıdır? }\end{array}$ & $\begin{array}{l}8 \text { Ülke, Nisan 2020- } \\
\text { Haziran } 2020\end{array}$ & $\begin{array}{l}\text { Yapay sinir } \\
\text { ağları }\end{array}$ & $\begin{array}{l}\text { Negatif yönde bir etki gerçekleşmiştir. Öngörülen GSYH rakamları cari yılın Nisan- } \\
\text { Haziran çeyreğinde tüm ülkelerde keskin düşüşler yaşamıștır. }\end{array}$ \\
\hline $\begin{array}{l}\text { Jie Li, } \\
\text { vd. }(2020)\end{array}$ & $\begin{array}{l}\text { COVID-19'un hanehalkı likidite } \\
\text { kısitlamaları üzerinde etkisi var mıdır? }\end{array}$ & $\begin{array}{l}\text { Çin, Mart 2020-Mayis } \\
2020\end{array}$ & $\begin{array}{l}\text { Regresyon } \\
\text { analizi }\end{array}$ & $\begin{array}{l}\text { Pozitif etkisi vardır. Hanehalkı likiditesindeki bozulma ise tasarruf istekliliklerini } \\
\text { önemli ölçüde arttırmakta ve tüketimini azaltmaktadır. }\end{array}$ \\
\hline $\begin{array}{l}\text { Just, M., ve } \\
\text { Echaust, K. } \\
\text { (2020) }\end{array}$ & $\begin{array}{l}\text { COVID-19 döneminde oynaklık, borsa } \\
\text { getirileri ve piyasa likitidesi arasındaki } \\
\text { ilişki nasıldır? }\end{array}$ & ABD ve 12 Ülke, & $\begin{array}{l}\text { Markov } \\
\text { değiştirme } \\
\text { modeli }\end{array}$ & $\begin{array}{l}\text { Bulgular, getiriler ile hem zımni oynaklık hem de zımni korelasyon arasında yakın } \\
\text { bir bağımlılık olduğunu, ancak likidite ile olmadığını göstermektedir. }\end{array}$ \\
\hline $\begin{array}{l}\text { Lan, C., Huang, } \\
\text { Z., ve Huang, } \\
\text { W. (2020) }\end{array}$ & $\begin{array}{l}\text { COVID-19 finans endüstrisindeki } \\
\text { sistemik riskleri arttırmış mıdır? }\end{array}$ & $\begin{array}{l}\text { Çin, } 2 \text { Aralık 2019-31 } \\
\text { Mayıs } 2020\end{array}$ & $\begin{array}{l}\text { Dinamik } \\
\text { CoVAR analizi }\end{array}$ & $\begin{array}{l}\text { Sistemik riskleri arttırmıştır. Menkul kıymetler üzerindeki etkisi daha büyük } \\
\text { gerçekleşmiştir. }\end{array}$ \\
\hline $\begin{array}{l}\text { Liu, L., vd. } \\
(2020)\end{array}$ & $\begin{array}{l}\text { COVID-19 ile ham petrol fiyatları ve } \\
\text { borsa arasında etkileşim var mıdır? }\end{array}$ & $\begin{array}{l}\text { ABD, } 21 \text { Ocak 2020-6 } \\
\text { Mayis } 2020\end{array}$ & $\begin{array}{l}\text { TVP-VAR } \\
\text { analizi }\end{array}$ & $\begin{array}{l}\text { COVID-19 ile pozitif bir etkileşimleri vardır. Ayrıca ham petrol getirileri ile hisse } \\
\text { senedi getirileri arasında negatif bir ilişki gözlemlenmektedir. }\end{array}$ \\
\hline $\begin{array}{l}\text { Mazumder, S. } \\
(2020)\end{array}$ & $\begin{array}{l}\text { COVID-19 döneminde FED } \\
\text { açıklamalarına borsa tepkileri sosyal } \\
\text { güvenin değeri hangi yönde değişmiştir? }\end{array}$ & ABD-23 Mart 2020 & $\begin{array}{l}\text { Regresyon } \\
\text { analizi }\end{array}$ & $\begin{array}{l}\text { Pozitif yönde değişmiştir. Yüksek güven eyaletlerinde bulunan firmalar, diğer dış̧ } \\
\text { finansmanlara daha ucuza erişebildikleri için duyurulardan daha az yararlanmışardır. }\end{array}$ \\
\hline $\begin{array}{l}\text { Nguyen, D. T., } \\
\text { vd. }(2021)\end{array}$ & $\begin{array}{l}\text { COVID-19 döneminde ABD ve Çin } \\
\text { hisse senedi piyasalarının küresel hisse } \\
\text { senedi piyasaları üzerinde bir etkisi } \\
\text { olmuş mudur? }\end{array}$ & $\begin{array}{l}12 \text { Hisse senedi endeksi, } 1 \\
\text { Temmuz 2019-30 Haziran } \\
2020\end{array}$ & $\begin{array}{l}\text { Granger } \\
\text { nedensellik } \\
\text { yöntemi }\end{array}$ & $\begin{array}{l}\text { Bir etki meydana gelmiştir. ABD ve Çin borsalarından küresel borsalara bulaşıcı etki } \\
\text { vardır. Hisse senedi endeksi oynaklığı ise zayıftır. }\end{array}$ \\
\hline $\begin{array}{l}\text { O'Donnell, N., } \\
\text { vd. (2021) }\end{array}$ & $\begin{array}{l}\text { COVID-19 ile uluslararası hisse senedi } \\
\text { endeksi fiyatları arasında bir bağlantı } \\
\text { var mıdır? }\end{array}$ & $\begin{array}{l}\text { Çin, İtalya, İspanya, } \\
\text { Birleşik Krallık, ABD, } \\
\text { Aralık 2019-Haziran } 2020\end{array}$ & $\begin{array}{l}\text { Çoklu doğrusal } \\
\text { regresyon }\end{array}$ & $\begin{array}{l}\text { Negatif yönlü bir bağlantı vardır. COVID-19 vakalarındaki artış hisse senedi } \\
\text { fiyatlarında değişikliğe yol açmaktadır. }\end{array}$ \\
\hline $\begin{array}{l}\text { Ortmann, R., } \\
\text { vd. }(2020)\end{array}$ & $\begin{array}{l}\text { Perakende yatırımcılar COVID-19'a } \\
\text { nasil tepki vermiştir? }\end{array}$ & $\begin{array}{l}\text { Birleşik Krallık, } 1 \text { Ağustos } \\
2020-17 \text { Nisan } 2020\end{array}$ & OLS yöntemi & $\begin{array}{l}\text { Yatırımcılar ortalama olarak mevduatlarını ve daha fazla yeni hesap açarak işlem } \\
\text { yoğunluğunu artırmaktadırlar. COVID-19 vakalarının sayısı iki katına çıkınca } \\
\text { haftalık ortalama ticaret yoğunluğu \%13,9 artmıştır. }\end{array}$ \\
\hline $\begin{array}{l}\text { Pengcheng } \\
\text { Song, } \\
\text { vd. }(2020)\end{array}$ & $\begin{array}{l}\text { Endüstriyel yapının COVID-19 } \\
\text { sirasında dışsal şoklar altında gelişen } \\
\text { farklı pazarlardaki performansı hangi } \\
\text { yönde değişmiştir? }\end{array}$ & Çin ve Vietnam & $\begin{array}{l}\text { Sistem } \\
\text { dinamiği } \\
\text { simülasyon } \\
\text { tekniği }\end{array}$ & $\begin{array}{l}\text { Bir ülkenin şok absorbe etme kabiliyetinde önemli farklılıklar olduğu sonucuna } \\
\text { ulaşılmıştır. Şokun büyüklüğü değil şokun türü ve endüstriyel yapı ile ilgilidir. }\end{array}$ \\
\hline $\begin{array}{l}\text { Rahman, M. L., } \\
\text { vd. (2021) }\end{array}$ & $\begin{array}{l}\text { COVID-19'un Avustralya borsasında } \\
\text { yarattığı tepkiler nelerdir? COVID-19 } \\
\text { ile mücadelede hükümet teşvik } \\
\text { politikaları güveni yeniden sağlamış } \\
\text { mıdır? }\end{array}$ & $\begin{array}{l}\text { Avustralya- } 30 \text { Ocak 2020- } \\
11 \text { Mart } 2020 \text { ve } 22 \text { Mart } \\
2020-8 \text { Nisan } 2020\end{array}$ & Vak'a analizi & $\begin{array}{l}\text { Pandeminin ortaya çıkması borsa üzerinde olumsuz etki yaratmıştır. Hükümet } \\
\text { teşviklerinden sadece "JobKeeper" paketine olumlu tepki verilmiştir. }\end{array}$ \\
\hline
\end{tabular}


Tablo 1 (Devamı): COVID-19'un Ekonomik Etkileri Ampirik Literatür

\begin{tabular}{|c|c|c|c|c|}
\hline Yazar(lar) & Araştırma Sorusu & Örneklem/Zaman Dilimi & Yöntem & Ampirik Bulgular ve Değerlendirme \\
\hline $\begin{array}{l}\text { Rizwan, M. S., } \\
\text { vd. (2020) }\end{array}$ & $\begin{array}{l}\text { COVID-19'dan en çok etkilenen sekiz } \\
\text { ülkedeki sistemik risk hangi } \\
\text { düzeydedir? }\end{array}$ & $\begin{array}{l}8 \text { Ülke, } 2 \text { Ocak 2006-27 } \\
\text { Nisan } 2020\end{array}$ & $\begin{array}{l}\text { GPB ve SGED } \\
\text { analizi }\end{array}$ & $\begin{array}{l}\text { Salgın döneminde sistemik riskte keskin bir artış olduğu ancak yüksek seviyelerde } \\
\text { durgunluk gözlendiği sonucuna ulaşılmıştır. }\end{array}$ \\
\hline $\begin{array}{l}\text { Sakurai, Y., ve } \\
\text { Kurosaki, T. } \\
\text { (2020) }\end{array}$ & $\begin{array}{l}\text { COVID-19 döneminde petrol ve ABD } \\
\text { borsası arasında ilişki var mıdır? }\end{array}$ & $\begin{array}{l}\text { ABD, } 18 \text { Mayıs } 2010-31 \\
\text { Ocak } 2020 \text { ve } 3 \text { Şubat } \\
2020-31 \text { Mayıs } 2020\end{array}$ & $\begin{array}{l}\text { GARCH } \\
\text { analizi }\end{array}$ & $\begin{array}{l}\text { Salgın sonrasında hem yukarı hem aşă̆ı yönlü korelasyonların arttığı } \\
\text { gözlemlenmiş̧tir. Korelasyon asimetresi salgın başladıktan sonra daha belirgin hale } \\
\text { gelmiştir. }\end{array}$ \\
\hline $\begin{array}{l}\text { Salisu, A. A., } \\
\text { vd. }(2020)\end{array}$ & $\begin{array}{l}\text { Küresel korku endeksi COVID-19 } \\
\text { döneminde emtia fiyat getirilerinin } \\
\text { öngörülebilirliğinde tahmin gücünü } \\
\text { hangi yönde etkilemiştir? }\end{array}$ & $\begin{array}{l}11 \text { Mart 2020-18 Mayıs } \\
2020\end{array}$ & $\begin{array}{l}\text { Panel } \\
\text { regresyon } \\
\text { analizi }\end{array}$ & $\begin{array}{l}\text { Emtia fiyat getirileri ile küresel korku endeksi arasında pozitif yönlü bir ilişki vardır. } \\
\text { COVID-19 ile ilgili korku arttıkça emtia getirileri artmaktadır. Ayrıca bu dönemde } \\
\text { emtia getirileri borsa getirilerinden daha güvenli olduğu kanaatine varılmıştır. }\end{array}$ \\
\hline $\begin{array}{l}\text { Shehzad, K., vd. } \\
(2020)\end{array}$ & $\begin{array}{l}\text { COVID-19 ve küresel finans krizi } \\
\text { döneminde seçilen beş ülkenin finansal } \\
\text { piyasalarının doğrusal olmayan } \\
\text { davranışı nasıldır? }\end{array}$ & $\begin{array}{l}5 \text { Ülke, } 30 \text { Haziran } 2007-7 \\
\text { Nisan } 2020\end{array}$ & $\begin{array}{l}\text { Asymmetric } \\
\text { Power } \\
\text { GARCH }\end{array}$ & $\begin{array}{l}\text { COVID-19'un S\&P } 500 \text { 'ün hisse senedi getirileri üzerinde önemli ve zararlı bir etkisi } \\
\text { olduğu; ancak Nasdaq Bileşik endeksi üzerinde önemsiz bir etki gösterdiği sonucuna } \\
\text { ulaşılmıstır. Avrupa ve ABD pazarları, Asya pazarlarına kıyasla COVID-19'dan daha } \\
\text { fazla etkilenmektedir. }\end{array}$ \\
\hline $\begin{array}{l}\text { Sherif, M. } \\
(2020)\end{array}$ & $\begin{array}{l}\text { COVID-19'un İngiltere Dow Jones } \\
\text { piyasa endeksi üzerinde kısa vadeli } \\
\text { etkisi var mıdır? }\end{array}$ & $\begin{array}{l}\text { İngiltere, } 20 \text { Ocak 2020-20 } \\
\text { Mayis } 2020\end{array}$ & $\begin{array}{l}\text { Panel } \\
\text { regresyon } \\
\text { analizi }\end{array}$ & $\begin{array}{l}\text { COVID-19 ile geleneksel borsa endeksinin performansı arasında güçlü bir ilişki } \\
\text { vardır. Ayrıca bilgi teknolojisi sektörünün hisse senedi getirilerinin piyasadan önemli } \\
\text { ölçüde daha iyi performans gösterdiğini; oysa tüketici isteğine bağl1 sektörün hisse } \\
\text { senedi getirileri, COVID-19 salgını sırasında pazardan önemli ölçüde daha kötü } \\
\text { performans gösterdiği sonucuna ulaş1lmıştır. }\end{array}$ \\
\hline $\begin{array}{l}\text { Sifat, I., vd. } \\
(2021)\end{array}$ & $\begin{array}{l}\text { Enerji ve değerli metal vadeli } \\
\text { işlemlerinde spekülasyonlar COVID-19 } \\
\text { döneminde yaygınlaşmış mıdır? }\end{array}$ & Dünya & $\begin{array}{l}\text { Kuantil } \\
\text { regresyon } \\
\text { analizi }\end{array}$ & COVID-19 ile spekülasyonlar arasında doğrusal olmayan bir ilişki vardır. \\
\hline $\begin{array}{l}\text { Smith, L. V., } \\
\text { vd. }(2020)\end{array}$ & $\begin{array}{l}\text { COVID-19'un küresel fosil yakıt } \\
\text { tüketimi ve } \mathrm{CO}_{2} \text { emisyonları üzerinde } \\
\text { etkisi var mıdır? }\end{array}$ & 2020Q1-2021Q4 & GVAR analizi & $\begin{array}{l}\text { Pozitif yönde bir etki meydana getirmiştir. Ayrı̈ca küresel ölçekte karbon } \\
\text { fiyatlandırması nedeniyle fosil yakıtlardaki göreli fiyat değişikliğinin tüketim ve } \\
\text { üretim üzerindeki etkisi de simüle edilmiştir. }\end{array}$ \\
\hline $\begin{array}{l}\text { So, M. K., vd. } \\
(2021)\end{array}$ & $\begin{array}{l}\text { COVID-19'un Hong Kong finans } \\
\text { piyasası üzerinde etkisi var mıdır? }\end{array}$ & $\begin{array}{l}\text { Hong Kong, } 3 \text { Ocak 2006- } \\
30 \text { Ekim } 2020\end{array}$ & $\begin{array}{l}\text { Dinamik ağ } \\
\text { yaklaşımı }\end{array}$ & $\begin{array}{l}\text { COVID-19'un Hong Kong finans piyasası üzerinde negatif etkisi vardır. COVID-19 } \\
\text { döneminde kısmi korelasyon ağlarında hem ağ yoğunluğu hem de kümelenme daha } \\
\text { yüksektir. }\end{array}$ \\
\hline $\begin{array}{l}\text { Størdal, S., vd. } \\
(2021)\end{array}$ & $\begin{array}{l}\text { COVID-19 ile mücadelede hükümet } \\
\text { sübvansiyonlarının, okulları kapatılması } \\
\text { kararının ve seyahat yasaklarının borsa } \\
\text { getirileri üzerinde etkisi var mıdır? }\end{array}$ & $\begin{array}{l}\text { Norveç ve İsveç, } 1 \text { Ocak } \\
2020-5 \text { Kasım } 2020\end{array}$ & Panel OLS & $\begin{array}{l}\text { Olumlu etkisi olmuştur. Ancak etki gücü COVID-19 vakalarının artmasıyla } \\
\text { zayıflamıştır. Farmasötik olmayan müdahalelerin Norveç borsa getirileri üzerinde } \\
\text { çok az etkisi olduğunu veya hiç etkisi olmadığını, hisse senedini olumlu etkilediğini } \\
\text { göstermektedir. }\end{array}$ \\
\hline $\begin{array}{l}\text { Umar, Z., ve } \\
\text { Gubareva, M. } \\
\text { (2020) }\end{array}$ & $\begin{array}{l}\text { COVID-19'un itibari para ve kripto para } \\
\text { piyasalarının oynaklığı üzerinde etkisi } \\
\text { var mıdır? }\end{array}$ & Ocak 2020- Mayıs 2020 & $\begin{array}{l}\text { Dalgacik } \\
\text { analizi }\end{array}$ & $\begin{array}{l}\text { Koronavirüs Panik Endeksi ile EUR, GBP, RMB arasında yüksek tutarlılık vardır. } \\
\text { Ayrıca panik endeksi ile } 11 \text { büyük kripto para birimi arasında da yüksek tutarlılık } \\
\text { vardır. }\end{array}$ \\
\hline $\begin{array}{l}\text { Wang, K.-H., ve } \\
\text { Su, C.-W. } \\
\text { (2021) }\end{array}$ & $\begin{array}{l}\text { COVID-19 ile fosil enerji fiyatları } \\
\text { arasında Granger nedenselliği var mıdır? }\end{array}$ & $\begin{array}{l}13 \text { Ocak 2020-30 Kasim } \\
2020\end{array}$ & $\begin{array}{l}\text { Fourier } \\
\text { Granger } \\
\text { Nedensellik } \\
\text { analizi }\end{array}$ & $\begin{array}{l}\text { COVID-19 ile petrol ve doğal gaz fiyatları arasında Granger nedenselliği vardır. } \\
\text { Ancak kömür piyasasında bir nedensellik keşfedilmemiştir. }\end{array}$ \\
\hline $\mathrm{Xu}, \mathrm{L} .(2021)$ & $\begin{array}{l}\text { COVID-19 döneminde ABD ve Kanada } \\
\text { borsa getirileri hangi yönde değişmiştir? }\end{array}$ & $\begin{array}{l}\text { ABD ve Kanada, } 27 \text { Ocak } \\
2020-2 \text { Temmuz } 2020\end{array}$ & $\begin{array}{l}\text { GARCH ve } \\
\text { Ortalama VAR } \\
\text { analizi }\end{array}$ & $\begin{array}{l}\text { COVID-19 belirsizliği borsa getirilerini olumsuz etkilemektedir. Kanada'daki } \\
\text { vakalardaki artı̧s ve azalışta borsa tepkileri asimetriktir. }\end{array}$ \\
\hline
\end{tabular}


Tablo 1 (Devamı): COVID-19'un Ekonomik Etkileri Ampirik Literatür

\begin{tabular}{|c|c|c|c|c|}
\hline Yazar(lar) & Araştırma Sorusu & Örneklem/Zaman Dilimi & Yöntem & Ampirik Bulgular ve Değerlendirme \\
\hline $\begin{array}{l}\text { Yagi, M., ve } \\
\text { Managi, S. } \\
(2021)\end{array}$ & $\begin{array}{l}\text { COVID-19 krizi ve } 2008 \text { mali krizi } \\
\text { kaynaklı tedarik zinciri hasarları } \\
\text { arasında nasıl farklılıklar vardır? }\end{array}$ & 35 Ülke & $\begin{array}{l}\text { Arz odaklı IO } \\
\text { modeli }\end{array}$ & $\begin{array}{l}\text { COVID-19 kaynaklı hasar } 4 \text { ay boyunca \%1.248 olmuştur bu değer } 2008 \text { krizinin } 1.4 \\
\text { katıdır. Küresel bir krizle karşı karşıya kalıken, sadece tedarik zincirindeki } \\
\text { aksaklıkları değil, aynı zamanda sağlık ve hizmet sektörleri üzerindeki etkilerini de } \\
\text { dikkate almak gerekir. }\end{array}$ \\
\hline $\begin{array}{l}\text { Yan, L., ve } \\
\text { Qian, Y. (2020) }\end{array}$ & $\begin{array}{l}\text { Perakendecilik endüstrisinin hisse } \\
\text { senedi fiyatları üzerinde COVID-19'un } \\
\text { etkisi var mıdır? }\end{array}$ & Çin & $\begin{array}{l}\text { Vak'a } \\
\text { incelemesi }\end{array}$ & $\begin{array}{l}\text { Geçici bir etki vardır. Etkinin geçici olmasının nedeni hükümetin uyguladığı } \\
\text { politikaların zaman tutarlı olmasından kaynaklanmaktadır. }\end{array}$ \\
\hline $\begin{array}{l}\text { Yang, H. ve } \\
\text { Deng, P. (2021) }\end{array}$ & $\begin{array}{l}\text { COVID-19 ile mücadelede hükümet } \\
\text { müdahalelerinin borsa üzerindeki etkisi } \\
\text { nedir? }\end{array}$ & $\begin{array}{l}20 \text { OECD Ülkesi, } 1 \text { Şubat } \\
\text { 2020-1 Ekim } 2020\end{array}$ & $\begin{array}{l}\text { Panel } \\
\text { regresyon } \\
\text { analizi }\end{array}$ & $\begin{array}{l}\text { Pozitiftir. İradi hükümet politikaları borsa getirisi üzerinde etkiye sahipken destek } \\
\text { politikaları gibi dolaylı hükümet politikalarının borsa getirisi üzerinde etkisi yoktur. }\end{array}$ \\
\hline $\begin{array}{l}\text { Yu, Z., vd. } \\
(2021)\end{array}$ & $\begin{array}{l}\text { Salgınların ülkelerin ihracatı üzerinde } \\
\text { uzun vadeli etkisi olmuş mudur? }\end{array}$ & 1951-2015 & $\begin{array}{l}\text { Regresyon } \\
\text { analizi }\end{array}$ & $\begin{array}{l}\text { Negatif etkisi olmuştur. Salgınlar ne kadar büyükse olumsuz etki o kadar büyük olur. } \\
\text { Salgından etkilenen ülkelerdeki ticaret toparlanması V şeklinde değil, U şeklindedir. }\end{array}$ \\
\hline
\end{tabular}

Bu tablo, yazarlar, araștırma sorusu, örneklem/zaman dilimi, yöntem ve ampirik bulgular ve değerlendirme sütunlarından oluşmaktadır. COVID-19 'un ekonomik etkileri üzerine hazırlanan çeşitli ampirik araştırmaları içermektedir. COVID-19 ile ilgili olarak derlenen bu araştırmaların sonuçları finansal piyasalar, döviz piyasası, enerji fiyatları ve kamu harcamaları özelinde sırasıyla üçüncü, dördüncü, beşinci ve altıncı bölümlerde tartışılmaktadır. 


\section{COVID-19 VE FINANS PIYAASASI}

COVID-19 salgını küresel ekonomide büyük bir belirsizliği tetiklemiştir. Belirsizliğin neden olduğu panik yatırıcımlar arasında hızla yayılmış ve finansal piyasaları olumsuz yönde etkilemiştir (Iyke, 2020). Ayrıca Rizvan vd. (2020) ve Lan vd. (2021) COVID-19'un finans endüstrisindeki sistemik riskleri arttırarak sistemdeki bozulmayı göstermiştir. COVID-19 dünya çapında belirsizlik ve hisse senedi getirisinde azalmalara neden olarak finansal piyasaları olumsuz yönde etkilemiştir. Piyasaların olumsuz yönde etkilenmesi sermaye akışlarını da azaltmıştır. O’Donnell vd. (2021) altı gelişmiş ülke borsalarındaki salgın dönemi öncesi ve sonrası borsa getirilerini incelemiş ve aralarında güçlü negatif yönlü bir ilişkinin varlığını keşfetmiştir. Hisse senedi ve piyasa belirsizliğinden kaynaklanan bu bozulmalar küresel finans sisteminde yatırım, proje finansmanı ve likitide mevcudiyetinde engeller yaratmıştır (Padhan ve Prabheesh, 2021).

Ampirik kanıtlar, COVID-19 salgınının borsa getirisini olumsuz etkilediğini ve artan hisse senedi getirisi oynaklığını arttırdığını göstermektedir (Umar ve Gubareva, 2020; Bal ve Mohanty, 2021; Engelhardt vd., 2021). Baig vd. (2021)'nin ABD borsa getirilerinin mikro yapısı üzerine yaptı̆̆ araştırmada COVID-19'un hisse senedi piyasaları üzerindeki mikro etkileri gösterilmektedir. Bu etkilerin COVID-19 vaka sayılarındaki artışla piyasadaki likitide ve oynaklıkla yakından ilişkili olduğu gözlemlenmektedir (Albulescu, 2021). Ayrıca borsa oynaklığı COVID-19 vakalarına karşı oldukça duyarlıdır (Baek vd., 2020; Just ve Echaust, 2020; So vd., 2021).

Finansal piyasalardaki bu olumsuzluklar kripto para piyasasında da etkili olmuştur. Ancak bu etki olumsuz bir etki değildir. COVID-19 salgınının ortaya çıkması ile beraber kripto para birimlerinin değerlerinde bir artış meydana gelmiştir (Goodell ve Goutte, 2021). Kripto para birimlerinin hala güvenli bir liman olup olmadığı tartışması sürerken kriz ile beraber bu artışlar dikkat çekicidir. Hisse senedi getirileri üzerinden gerçekleşen V şeklindeki iyileşme davranışı kripto para birimlerinde özellikle de Bitcoin'de daha hılılı oluşmuştur. 5 Nisan sonrası dönemde Bitcoin ve türevleri hızlı bir artış göstermiştir.

Şekil 1, COVID-19 salgınından en çok etkilenen ilk 10 ekonominin borsasındaki eğilimleri göstermektedir. Şekilde Mart 2020'de ciddi bir düşüş gözlemlenmiştir. Borsa Mayıs ayından sonra toparlanma eğilimine geçiş yapmıştır. Bu toparlanma, hükümetlerin COVID-19 ile mücadelede aldıkları kararların bir sonucu olarak değerlendirilebilir (Ashraf, 2020; Yang ve Deng, 2021; Stordal vd., 2021; Rahman, 2021). Borsadaki düzelme eğilimleri genellikle V şeklinde oluşmuştur. Kamu duyarlılığın artması ve korkudan umuda geri dönülmesi piyasaları da olumlu yönde etkilemiştir. Finansal piyasaların V şeklindeki davranışı iyileşmenin habercisi olarak da belirtilebilir (Ngo ve Nguyen, 2021). Ayrıca borsadaki bu toparlanmalar ülkeler arasında farklılık göstermektedir. Fernandez vd., (2021) bu farklılığın temel sebebini ülkelerin ulusal kültürlerinin farklılığına bağlamaktadır.

\section{COVID-19 VE DÖVIZZ KURU}

Döviz kuru bir ekonominin dış istikrarının korunmasında oldukça önemli bir role sahiptir. Döviz kuru; doğrudan ticaret dengesi, ihracat rekabet gücü, dış borç ve sermaye akışları ile yakından ilişkili olduğundan, döviz kurundaki dalgalanmalar politika yapıcıları endişelendiren iktisadi sorunlardan biridir (Padhan ve Prabheesh, 2021). COVID-19 salgınının başlangıcıyla birlikte küresel mal ticareti keskin bir düşüş yaşamıştır. Küresel ticaret hacimlerindeki keskin düşüşler uluslararası sermaye akımlarının da kaçınılmaz olarak düşmesine neden olmuştur (Qin vd., 2020). Sermaye akımlarının bu keskin düşüşleri döviz kuru üzerinde de belirli etkiler meydana getirmiş ve döviz kuru oynaklığını arttırmıştır. Küresel sermaye akışlarının azalmasıyla birlikte finansal kuruluşların uluslararası finansal varlıklara yönelik dengesiz talepleri neticesinde varlıkların risk düzeylerinde artış meydana getirmiştir. Nitekim COVID-19 ile mücadelede hükümet müdahaleleri döviz kuru oynaklığını pozitif yönde etkilerken, kayıt altına alınmış vakalardaki artış da döviz kuru oynaklığını arttırmıştır (Feng vd., 2021).

COVID-19 döneminde birçok ekonomi sermaye çıkışları ve piyasa duyarlılıkları sebebiyle döviz kuru oynaklığında artış ve para birimlerinde değer kaybı yaşamıştır. Döviz kuru oynaklığındaki artış ve para birimin değer kaybetmesi hisse senedi fiyatları, sermaye girişleri ve dış yükümlülükler üzerinde bozucu etkiler meydana getirmiştir.

Şekil 2 COVID-19 salgınından en çok etkilenen 10 ülkenin döviz kurundaki aşırı oynaklığı göstermektedir. Tüm ekonomiler COVID-19'un ortaya çıkışı ile Nisan ayının ortasına kadar para birimlerinde değer kayıpları yaşamıştır. Salgının devam eden sürecinde ise bazı ülkelerin döviz kuru oynaklıkları azalmış ve döviz kurları değerlenmeye başlamıştır. Finansal piyasalarda gözlenen $V$ şeklindeki finansal piyasa davranışı döviz kuru için de geçerli olmuştur. Tekrardan düzelme eğilimine giren döviz kuru hükümetlerin COVID-19 ile mücadele önlemlerinin de bir sonucu olabilir. 


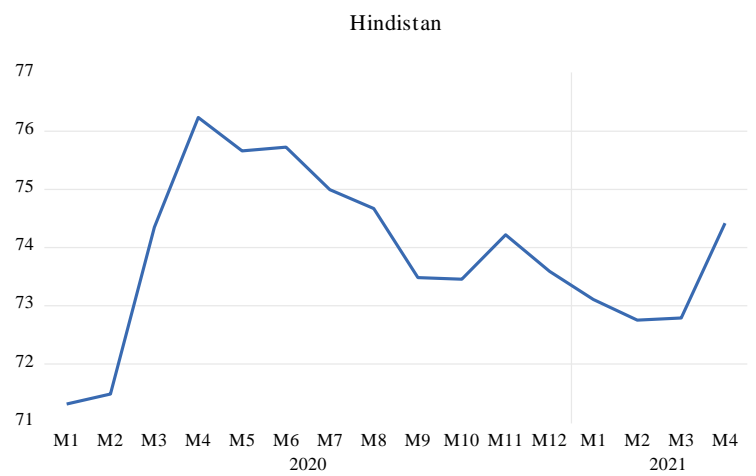

Avro Bölgesi

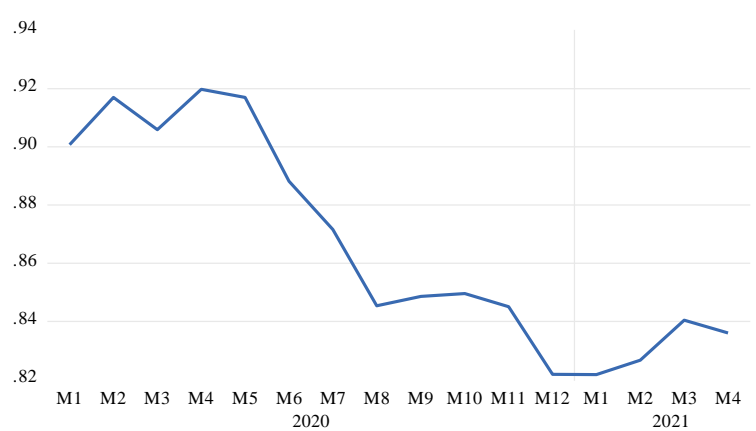

Türkiye

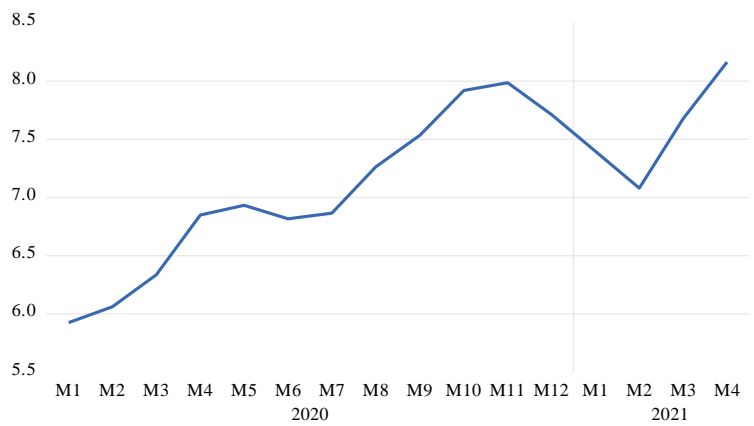

Brezily a

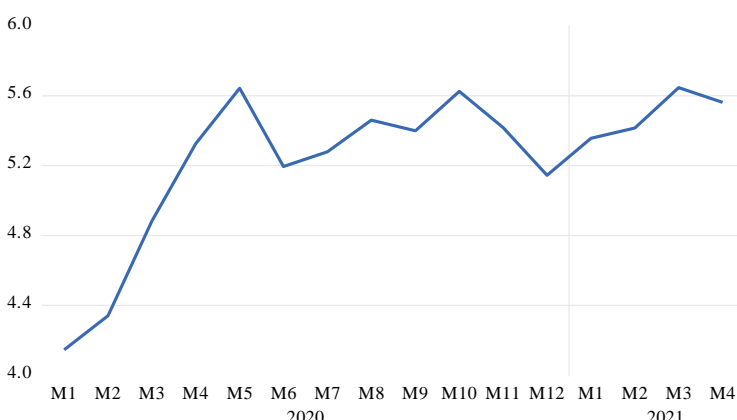

Rusya

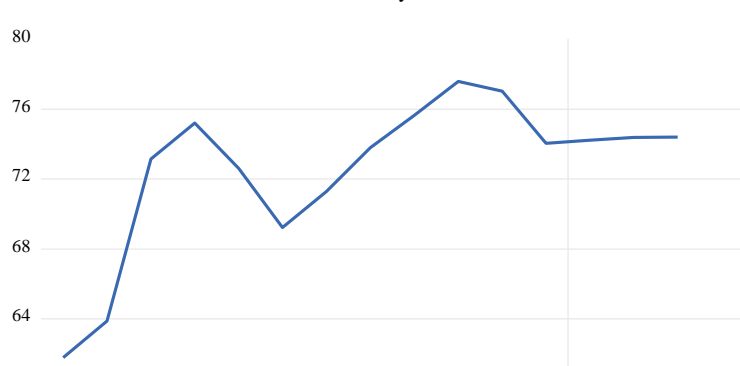

60

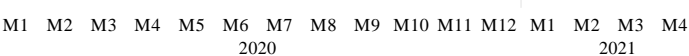

Birleșik Krallık

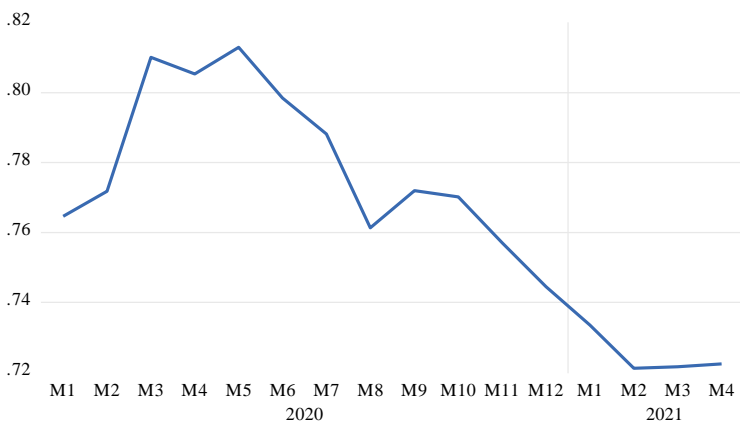

Şekil 1. COVID-19'dan En Çok Etkilenen Ülkelerin Döviz Kurlarının Gelişimi

\section{COVID-19 İLE MÜCADELEDE HÜKÜMET MÜDAHALELERİ VE KAMU HARCAMALARI}

COVID-19 salgınının yalnızca sağlık sistemlerini değil aynı zamanda ekonomik ve finansal sistemlere de ciddi zararlar verdiği birçok çalışma tarafından doğrulanmıştır. Hükümetler finansal ve ekonomik sistem üzerindeki bozucu etkileri ve ölüm oranlarını azaltmak için bazı önlemler almıştır ve almaya da devam etmektedir. Virüsün yayılmasını engellemek amacıyla ülkeler kısıtlama, kapanma vb. düzenlemeler yapmışlardır. Bu düzenlemelerin etkisini ölçmek için Alexakis vd., (2021) ülkelere göre COVID-19 ile mücadelede hükümet müdahale endeksi geliştirmişlerdir. Bu endeks kapsamına alınan ülkelerde başlangıçta alınan zayıf önlemlerin vaka sayılarındaki artışla beraber hızla arttığı tespit edilmiştir. Ancak Altman (2020) ise, bir ülkenin ekonomisinin tamamen kapatılmasının ölüm oranlarını en aza indirmek için bir çözüm olmayacağını ileri sürmüştür. Bu doğrultuda alınan önlemler ve müdahalelerin doğru tespit edilmesi, bireylerin seçim özgürlüğünün korunması bağlamında bireylerin kararlarını öngörülebilir şekillerde etkileyeceğinden dolayı önemlidir. Bir dürtme stratejisi üzerine kurulu müdahalelerin yanı sıra, katı bir tecritten ziyade kamusal davranış hakkında bir dizi tavsiyede bulunularak ölüm oranlarını daha düşük seviyelere indirmeyi başaran İsveç örneğini Størdal vd., (2021) kanıtlamıştır. Ancak etki gücünün vaka sayılarındaki artışla zayıfladığı da keşfedilmiştir.

Ashraf (2020) 22 Ocak 2020'den 17 Nisan 2020'ye kadar günlük veriler kullanarak 77 ülkede COVID-19 ile mücadelede hükümet müdahalelerin borsa getirileri üzerindeki etkisini incelemiştir. Bulgulara göre hükümet müdahalelerinin ekonomik 
faaliyetler üzerinde doğrudan olumsuz etkisi olduğunu sonucuna ulaşılmıştır. Ancak kamuoyu bilinçlendirme programları, karantina politikaları ve gelir destek paketleri gibi diğer müdahalelerin ise dolaylı olarak olumlu etkisi olduğu tespit edilmiştir. Bu bağlamda hükümetlerin COVID-19 ile mücadelede zorunlu kıldı̆̆ı sosyal mesafe önlemlerinin hem olumlu hem olumsuz ekonomik etkileri bulunmaktadır.

\section{COVID-19 VE ENERJI FIYYATLARI}

Petrol fiyatlarındaki tüm büyük dalgalanmaların, Ortadoğu'daki siyasi olayların neden olduğu petrol üretim akışındaki kesintilere bağlı olabileceği öne sürülmekteydi (Hamilton, 2003). Ancak son zamanlarda yapılan çalışmalar, yüksek belirsizlik zamanlarında fiyat esnekliğindeki artış nedeniyle arz ve talebin zaman içinde hızlı ve istikrarlı bir şekilde düştüğünü göstermektedir (Gil-Alana ve Monge, 2020). COVID-19 salgının belirsizliği ise emtia fiyatları üzerinde de ciddi bir etki meydana getirmiştir. Bu etki işgücü arzında azalmalara, seyahat kısıtlamalarına, ulaşım ve ticaretteki aksaklıklara doğrudan ve dolaylı olarak yol açarak ekonomiler için negatif bir arz şokuna neden olmuşlardır (Padhan ve Prabheesh, 2021). Ekonomik zorluklar ve küresel tedarik zincirlerinin ve lojistiğin bozulması nedeniyle enerji talebinin azalması talep yönlü şokları da ortaya çıkarmıştır. Meng Qin vd., (2020) küresel tedarik zincirleri üzerinde negatif bir etkiyi analitik olarak tespit etmiştir. Özellikle COVID-19 salgını sırasında uluslararası havayollarının ve kargo taşımacılığının kesintiye uğraması küreselleşme ile daha kırılgan bir hale gelen ticari faaliyetlerin askıya alınmasına neden olmuştur. Petrol üzerinde meydana gelen bu şokların küresel tüketimi ve yatırımı azalttığı tahmin edilmektedir (Padhan ve Prabheesh, 2021).

Liu vd., (2020) ham petrol fiyatları ve borsa arasında pozitif bir etkileşim olduğunu ampirik olarak ortaya koymuştur. Ayrıca ham petrol getirileri ve hisse senedi getirileri arasında negatif yönlü bir ilişkinin varlığını da tespit etmiştir. Salisu ve Adediran (2020), piyasa belirsizliğinin enerji piyasası oynaklığını öngörebileceğini gözlemlemiştir. Devpura ve Narayan (2020) ve Narayan (2020a), COVID-19 vakalarının ve ölümlerinin petrol fiyatlarındaki oynaklığı artırdığını ve büyük ölçüde petrol fiyatlarını etkilediğini ampirik olarak kanıtlamıştır. Huang ve Zheng (2020), yatırımcıların duyarlılığı ile ham petrol vadeli işlemleri arasındaki ilişkide yapısal değişiklikler olduğunu belirtmiştir. Yoshino vd., (2021)'e göre COVID-19 sürdürülebilir kalkınmaya yönelik yenilebilir enerji kaynaklarına yapılan yatırımları da etkilemektedir. Şöyle ki fosil yakıt fiyatlarının düşmesi sonucunda yenilenebilir enerji kaynaklarına yapılan yatırımlar negatif yönde etkilenmiştir.
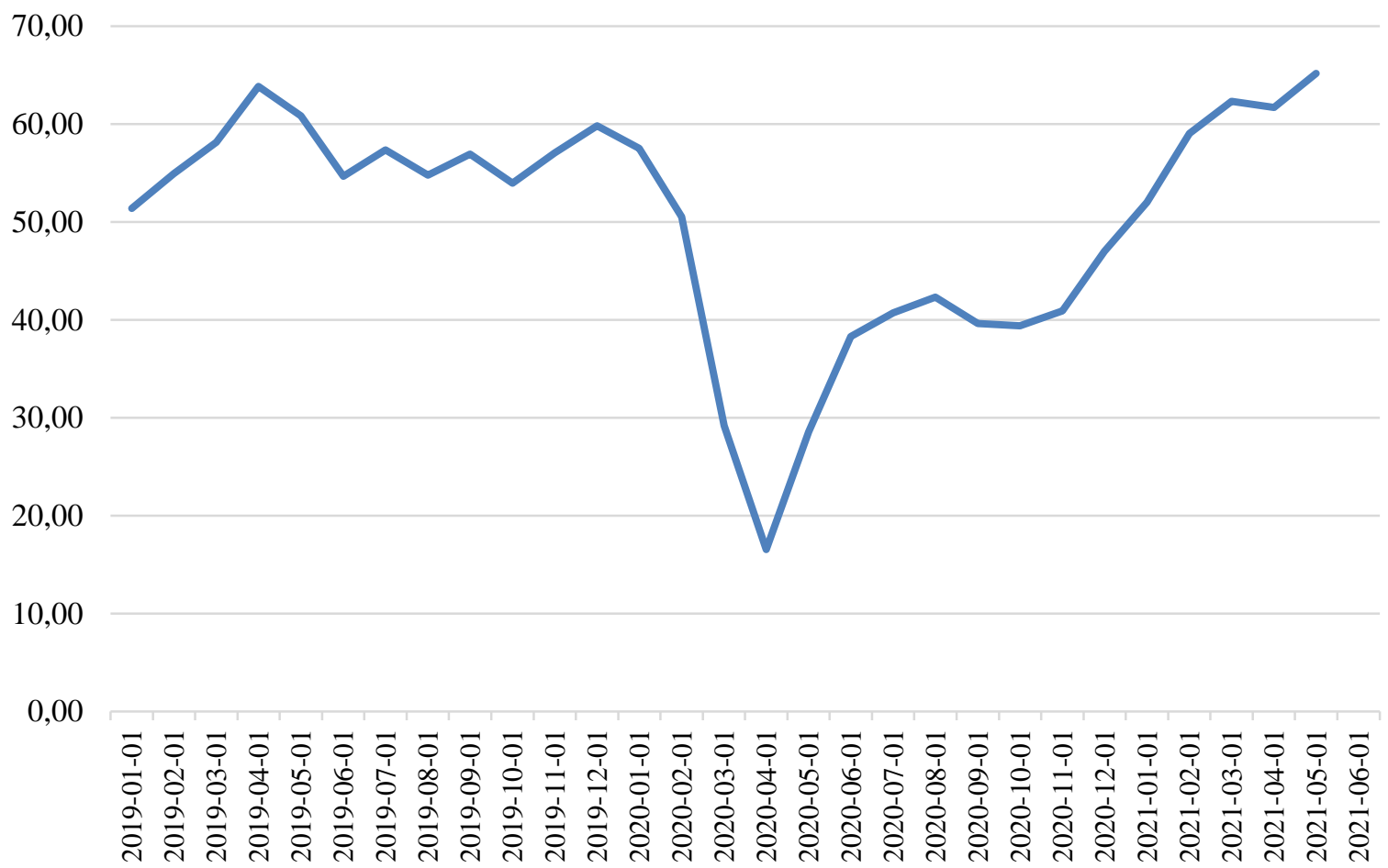

Şekil 2. Ham Petrol Fiyatlarının Gelişimi 


\section{COVID-19’UN EKONOMIK ETKİLERIYYL MÜCADELEDE POLITIIKA ÖNERILERİ}

Küresel salgınlar ekonomik üretim düzeyinde bir azalmaya ve işsiz sayısında bir artışa neden olmaktadır. COVID-19 salgını sırasında hükümetler bu hastalığın yayılma hızını ve ölümlü vakalarını sayısını azaltmaya yönelik önlemler almışlardır ve almaya da devam etmektedirler. İnsanın sosyal ve ekonomik hareketliliğini kısıtlayan bu önlemler doğrudan ekonomik faaliyetlerde ve dolaylı olarak istihdam düzeyinde önemli ölçüde azalmalara neden olmuştur. COVID-19'un yayılımını azaltmak amacıyla uygulanan sosyal mesafe önlemleri toplam ekonomik faaliyetlerde düşüşe neden olmuştur. Ekonomik hayattaki gerileme hükümetleri zor bir takas sorunu ile karşı karşıya bırakmıştır. Bu ikilem araştırmacıları optimum denge arayışlarında hükümetlerin para politikası, maliye politikası gibi geleneksel iktisat politikası araçlarının yanında politika koordinasyonu ve makroihtiyati politika araçlarını nasıl kullanabileceklerini tartışmaya teşvik etmiştir.

\subsection{Para Politikası}

COVID-19'un ekonomik etkilerini hafifletmek için para politikası önemli bir rol oynamaktadır. Bununla birlikte, devam eden salgın sırasında ekonomilerin uyguladığı para politikası araçlarının büyüklüğ̈ ve bileşenleri farklılıklar göstermektedir. Ancak uygulanan politikalar özellikle gelişmekte olan ekonomilerde döviz kurları ve sermaye akımlarındaki aşırı oynaklıktan dolayı istenilen etkiyi göstermemiştir (Hofmann vd., 2020). Gelişmekte olan ekonomiler enflasyon hedeflemesi ve makroihtiyati araçların yanı sıra döviz rezerv birikimlerini de arttırarak para politikalarının etkinliğini arttırmaya çalışmışlardır.

Enflasyon hedeflemesi, döviz kurunun enflasyon üzerindeki etkilerini azaltmaya yardımcı olurken, makroihtiyati araçlar, finansal sistemin esnekliğini desteklemiştir. Ayrıca, merkez bankaları para biriminin değer kaybetmesi, dış borçlanmalardaki temerrüt riski ve sermaye çıkışları ile baş etme kabiliyetine sahip olduğundan, rezervlerin birikimi gelişen ekonomiler üzerindeki şokları absorbe etmeye ve finansal stresi hafifletmeye yardımcı olabilecektir (Hofmann vd., 2020; Prabheesh, 2013). Büyük döviz rezervlerine sahip ekonomiler, salgın sırasında döviz piyasasına müdahale ederek para birimindeki değer kaybını yönetmeye çalışmaktadır. Bu kapsamda gelişmekte olan ülke merkez bankalarının yurtiçi likidite ve döviz piyasası durumunu dikkate alarak para politikaları benimsemesi gerekmektedir.

COVID-19 gelişmiş ekonomilerde daha düşük enflasyonla ilişkili olduğundan, genişletici para politikası daha yüksek ekonomik büyümeyi ve üretken sektöre daha yüksek yatırımı kolaylaştırabilir. Ancak gelişmiş ve gelişmekte olan ekonomilerin para politikaları birbirinden bağımsız değildir. Küresel para politikası ve buna bağlı şoklar, yurt içi makroekonomik koşulların ve para politikasının belirlenmesinde başat rol oynamaktadır. Buna göre, gelişmiş ekonomilerde para politikasının benimsenmesi, gelişmekte olan ekonomilerin para politikası kararlarını etkilemektedir (Prabheesh ve Vidya, 2018; Shareef ve Prabheesh, 2020). Bu bağlamda, salgın döneminde para politikasının makroihtiyati tedbirlerle desteklenmesi ekonomi politikasının etkinliğini iyileştirebilir.

\subsection{Makroihtiyati Politikalar}

COVID-19'un neden olduğu finansal istikrarsızlık göz önüne alındığında, makro ihtiyati politikalar, finansal sistemdeki istikrarın korunmasına ve sistematik risklerin azaltılmasına yardımcı olabilir. Buna göre, çok çeşitli makroihtiyati tedbirler, küresel finansal şoklara karşı direnci artırabilir. Bu önlemler banka sermayesini ve likiditeyi artıran, döviz risklerini sınırlayan ve riskli kredileri önleyen araçları içerir. Bu araçlar, bir ekonomiyi vuran küresel finansal şokları azaltmada heterojen bir etkiye sahiptir. Ayrıca, makroihtiyati düzenlemeler, yurt içi kredilerin küresel finansal şoklara duyarlılığını azaltmaktadır. Bu iddia, daha güçlü bir banka bilançosunun daha istikrarlı bir kredi arzına yol açtığı hipotezi ile uyumludur. Ek olarak, makroihtiyati düzenleme, döviz primi oynaklığını azaltan daha güvenli bir finansal sistem olarak nominal ve reel döviz kurlarını dengelemektedir. Makroihtiyati düzenlemeler, döviz kurlarındaki dalgalanmaların ve finansal istikrarı zedeleyebilecek sermaye akımlarının kontrol altına alınmasına yardımcı olacaktır. Bu durumda, makro ihtiyati düzenlemelerle birlikte para politikası, COVID-19'un olumsuz etkilerini azaltabilir ve daha yüksek ekonomik büyümeyi teşvik edebilir.

\subsection{Maliye Politikaları}

Maliye politikası, hanehalkları talebini etkili bir şekilde koruyabilir ve devam eden salgın sırasında ve bu olayın sonrasında toplam talep yoluyla ekonomilerin toparlanmasına yardımcı olabilir. Ekonomilerdeki kısıtlamaların sürekliliği göz önüne alındığında, insanları korumak için acil yaşam hatları oluşturmak için de maliye politikaları sağlık hizmetleri sektörüne uyarlanabilir (Chakraborty ve Thomas, 2020). Kısıtlamalar gevşetilirken uygulanacak maliye politikaları hanehalkları ve firmalara yapılacak sübvansiyonların büyüklüğü ve bileşenleri ile ekonomideki kayıt dışılığın kontrol altında tutulması gibi çok önemli konularda dikkatli kararlar verilmelidir. Uygulanacak doğru politikalar istihdamı desteklerken aynı zamanda işlere güvenli dönüşü teşvik etmeye ve salgın sonrasında ekonomilerin hızlı toparlanmasına yardımcı olacak yapısal düzenlemelerin verimliliğini arttıracaktır. Salgın yavaşladığında mali teşvikler, sağlık sistemleri ve fiziksel ve dijital altyapı için çok önemli olacaktır. Sınırlı mali alan durumunda, ekonomiler gelir üretmeli, harcamaları arttırmalı ve üretken yatırımları teşvik etmelidir. 
Mali riskleri azaltmak için tüm politika önlemlerinin şeffaf bir yönetimle orta vadeli bir mali çerçevede düzenlenmesi ve yürütülmesi gerekmektedir.

\subsection{Politika Koordinasyonu}

COVID-19 ile mücadelede ekonomik maliyetlerin büyüklüğü politika araçlarının ulusal ve uluslararası koordinasyonunu gerektirmektedir. Chakraborty ve Thomas (2020) COVID-19'a yönelik politika önerilerini daha fazla para ve maliye politikası koordinasyonun gerekli olduğunu belirtmektedirler. Ayrıca, sağlık ve tıbbi altyapının yanı sıra ticaret, finans ve makroekonomik politikalarda küresel koordinasyona ihtiyaç vardır. Ulusal düzeyde üçlü, yani para, makroihtiyati ve maliye politikaları arasındaki politika koordinasyonu, COVID-19'un etkilerini etkili bir şekilde azaltabilir.

Makroihtiyati politikanın temel amacı finansal istikrarı sağlamak ve sistematik riskten kaçınmak iken, para politikası fiyat istikrarını korumayı ve likiditeyi yönetmeyi amaçlamaktadır. Maliye politikasının amacı, toplam talebi artırmak ve mali tamponu kolaylaştırmaktır. Bir merkez bankasının fiyat ve finansal istikrarı artırmaya yönelik ikili hedefi kapsamında makro ihtiyati ve para politikaları arasında bir zaman tutarsızlığı sorunu kaçınılmazdır (Ueda ve Valencia, 2014). Böylece bu iki politika ex-ante ve ex-post eş zamanlı olarak kullanılabilir. Sonuç olarak, daha yüksek politika koordinasyonu, COVID-19'un etkilerini hafifletmede daha yüksek politika etkinliği sağlayacaktır.

\section{SONUÇ VE DEĞERLENDİRME}

Bu çalışmada, COVID-19'un ekonomik etkilerini araştıran makalelerin yöntemleri ve bulguları ile en çok etkilenen makroekonomik göstergeler ve bu olumsuz etki ile mücadelede öne çıkan politika önerileri tartışılmaktadır. Hazırlanan bu araştırma, COVID-19'un ekonomik etkileri doğrultusunda gelecekte yapılacak çalışmalar için detaylı bir ampirik literatür derlemesi sunmaktadır. Derlenen makalelerin ortak sonuçları 2020 yılının başlarında ortaya çıkan yeni tip koronavirüsün ekonomiyi derinden etkileyen sorunlara neden olduğunu açıkça göstermektedir. Literatür araştırması sonucunda elde edilen makalelerin ortak bulguları; COVID-19'un finans piyasası, döviz kurları ve enerji fiyatları üzerinde olumsuz birçok etkisinin olduğu, hükümetlerin COVID-19 ile mücadelede iradi para ve maliye politikalarının bileşenlerinde çeşitlenme ve büyüklüklerinde artışlar yaptığı, bu geleneksel politikaların yanında makroihtiyati politikalar ve politika koordinasyonu gibi modern iktisat politikası araçlarınında COVID-19'un ekonomik maliyetlerini kısa vadede hafifletmek için kullanıldığıdır.

Bilindiği gibi, tüm salgın hastalıklar ekonomik ve sosyal hayatı derinden etkileyen sonuçlara sahiptir. Ekonomik sorunların yanında hanehalklarının normal dışı davranışlarda bulunmalarına da sebep olmaktadır. Yeni bir tür koronavirüs olan COVID19 da bu etkilere sahip bir salgın hastalıktır. Kısa süre içerisinde bir milyonun üzerinde vakaya ve yüz binin üzerinde insanın ölümüne neden olmuştur. Bununların yanında; COVID-19 salgını yarattığı panik ortamı ile piyasa mekanizmalarını derinden etkileyerek, arz ve talep şoklarına da sebep olmuştur. Böyle bir ortamda yatırımcılar ve politika yapıcılar için COVID-19'un etkileri ile mücadelede etmek şokların kalıcı etkilerini en aza indirmek açısından daha da büyük önem arz etmektedir.

COVID-19 salgınının halen devam etmesi ve buna bağlı belirsizlik ortamı hanehalklarını yüksek ihtiyati tasarruf tedbirleri almaya yönlendirmektedir. Doğal olarak bu yönde alınan kararlar yatırımların sınırlı düzeyde gerçekleşmesine neden olmaktadır. Ekonomideki karar vericilerin salgın karşısındaki davrnışları ekonomik daralmanın şiddetini etkilemektedir. Salgının ne kadar süreceği ve ekonomik faaliyetler üzerindeki kısıtlamaların ne zaman kaldırılacağı hakkındaki bilinmezlik ekonomik kaybın ve ekonomik daralmanın hangi düzeyde olacağı konusunda tahminlerin yapılmasını da zorlaştırmaktadır. Dünya genelinde COVID-19 ile mücadelede alınan tedbirler ekonomik daralmanın hükümet politikalarıyla canlandırmasını amaçlasa da kullanılan iradi ve alternatif modern iktisat politikası araçlarının ekonomiyi canlandırmada neden yetersiz olduğu ve uzun vadeli olası bozucu etkilerinin nasıl giderilebileceği konusunda hem politika yapıcıları hem de araştırmacıları konuyu daha titiz incelemeleri konusunda motive etmektedir.

\section{KAYNAKÇA (REFERENCES)}

Akhtaruzzaman, M., Boubaker, S., ve Sensoy, A. (2021). Financial Contagion During COVID-19 Crisis. Finance Research Letters, 38, 1-14. Albulescu, C. T. (2021). COVID-19 and the United States Financial Markets' Volatility. Finance Research Letters, 38, 1-5.

Alexakis, C., Eleftheriou, K., ve Patsoulis, P. (2021). COVID-19 Containment Measures and Stock Market Returns: An International Spatial Econometrics Investigation. Journal of Behavioral and Experimental Finance, 29, 1-4.

Altman, M. (2020). Smart Thinking, Lockdown and Covid-19: Implications for Public Policy. Journal of Behavioral Economics for Policy, 4(COVID19 Special Issue), 23-33.

Amar, A. B., Belaid, F., Youssef, A. B., Chiao, B., ve Guesmi, K. (2021). The Unprecedented Reaction of Equity and Commodity Markets to COVID19. Finance Research Letters, 38, 1-7.

Ashraf, B. N. (2020). Economic Impact of Government Interventions During the COVID-19 Pandemic: International Evidence from Financial Markets. Journal of Behavioral and Experimental Finance, 27, 1-9. 
Azimli, A. (2020). The Impact of COVID-19 on the Degree of Dependence and Structure of Risk-return Relationship: A Quantile Regression Approach. Finance Research Letters, 36, 1-5.

Baek, S., Mohanty, S. K., ve Glambosky, M. (2020). COVID-19 and Stock Market Volatility: An Industry Level Analysis. Finance Research Letters, $37,1-10$.

Baig, A. S., Butt, H. A., Haroon, O., ve Rizvi, S. A. R. (2021). Deaths, Panic, Lockdowns and US Equity Markets: The Case of COVID-19 Pandemic. Finance Research Letters, 38, 1-9.

Bal, D., ve Mohanty, S. (2021). Sectoral Nonlinear Causality Between Stock Market Volatility and the COVID-19 Pandemic: Evidence From India. Asian Economics Letters, 2(1), 1-4.

Barrafrem, K., Västfjäll, D., ve Tinghög, G. (2020). Financial Well-being, COVID-19, and the Financial Better-Than-Average-Effect. Journal of Behavioral and Experimental Finance, 28, 1-5.

Bing, T. (2021). The Impact of COVID-19 on the Relation Between Retail Investors' Trading and Stock Returns in the Chinese Market. Asian Economics Letters, 2(1), 1-7.

BIS, (2019). Monetary policy frameworks in EMES: inflation targeting, the exchange rate and financial stability. Chapter II,Annual Economic Report June.

Cepoi, C. O. (2020). Asymmetric Dependence Between Stock Market Returns and News During COVID19 Financial Turmoil. Finance Research Letters, 36, 1-7.

Chiah, M., ve Zhong, A. (2020). Trading From Home: The Impact of COVID-19 on Trading Volume Around the World. Finance Research Letters, 37, $1-7$.

Chakraborty, L., Thomas, E., (2020). COVID-19 and Macroeconomic Uncertainty: Fiscal and Monetary Policy Response (No. 20/302), 1-7.

Chang Zhao, Ziwei Liu ve Yibing Ding (2020) How COVID-induced Uncertainty Influences Chinese Firms' OFDI Binary Margins, Emerging Markets Finance and Trade, 56(15), 3613-3625

Ciner, C. (2021). Stock Return Predictability in the time of COVID-19. Finance Research Letters, 38, 1-4.

Devpura, N., Narayan, P.K., (2020). Hourly Oil Price Volatility: The Role of COVID-19. Energy Res. Lett. 1(2), 1-5.

Engelhardt, N., Krause, M., Neukirchen, D., ve Posch, P. N. (2021). Trust and Stock Market Volatility during the COVID-19 Crisis. Finance Research Letters, 38, 1-6.

Espinosa-Méndez, C., ve Arias, J. (2021). COVID-19 Effect on Herding Behaviour in European Capital Markets. Finance Research Letters, 38, 1-6.

Fang, X., ve Cao, W. (2021). The Impact of COVID-19 on the Status of RMB as an Anchor Currency. Asian Economics Letters, 2(1), 1-5.

Fasanya, I. O., Oyewole, O. J., ve Oliyide, J. A. (2021). Can Uncertainty Due to Pandemic Predict Asia-Pacific Energy Stock Markets? Asian Economics Letters, 2(1), 1-7.

Feng, G. F., Yang, H. C., Gong, Q., ve Chang, C. P. (2021). What is the Exchange Rate Volatility Response to COVID-19 and Government Interventions?. Economic Analysis and Policy, 69, 705-719.

Fernandez-Perez, A., Gilbert, A., Indriawan, I., ve Nguyen, N. H. (2021). COVID-19 Pandemic and Stock Market Response: A Culture Effect. Journal of Behavioral and Experimental Finance, 29, 1-10.

Fu, Q., ve Chang, C.-P. (2021). How Do Pandemics Affect Government Expenditures? Asian Economics Letters, 2(1), 1-5.

Gharib, C., Mefteh-Wali, S., ve Jabeur, S. B. (2021). The Bubble Contagion Effect of COVID-19 Outbreak: Evidence From Crude Oil and Gold Markets. Finance research letters, 38, 1-10.

Gil-Alana, L. A., ve Monge, M. (2020). Crude Oil Prices and COVID-19: Persistence of the Shock. Energy Research Letters, 1(1), 1-4.

Goodell, J. W., ve Goutte, S. (2021). Co-movement of COVID-19 and Bitcoin: Evidence from Wavelet Coherence Analysis. Finance Research Letters, 38, 1-6.

Goswami, B., Mandal, R., ve Nath, H. K. (2021). Covid-19 Pandemic and Economic Performances of the States in India. Economic Analysis and Policy, 69, 461-479.

Hamilton, J. D. (2003). What is an Oil Shock?. Journal of Econometrics, 113(2), 363-398.

Han, H., ve Qian, Y. (2020). Did Enterprises' Innovation Ability Increase During the COVID-19 Pandemic? Evidence From Chinese Listed Companies. Asian Economics Letters, 1(3), 1-5.

Hofmann, B., Shim, I., Shin, H.S., (2020). Emerging Market Economy Exchange Rates and Local Currency Bond Markets Amid the Covid-19 Pandemic (no.5). In: Bank for International Settlements, 1-9.

IMF, J. (2020). A Crisis Like No Other, an Uncertain Recovery. World Economic Outlook Update.

Iyke, B. N. (2020). Economic Policy Uncertainty in Times of COVID-19 Pandemic. Asian Economics Letters, 1(2), 1-4.

Jena, P. R., Majhi, R., Kalli, R., Managi, S., ve Majhi, B. (2021). Impact of COVID-19 on GDP of Major Economies: Application of the Artificial Neural Network Forecaster. Economic Analysis and Policy, 69, 324-339.

Jie Li, Quanyun Song, Changyan Peng ve Yu Wu (2020) COVID-19 Pandemic and Household Liquidity Constraints: Evidence from Micro Data, Emerging Markets Finance and Trade, 56(15), 3626-3634.

Just, M., ve Echaust, K. (2020). Stock Market Returns, Volatility, Correlation and Liquidity During the COVID-19 Crisis: Evidence from the Markov Switching Approach. Finance Research Letters, 37, 1-8.

Lan, C., Huang, Z., ve Huang, W. (2020). Systemic Risk in China's Financial Industry Due to the COVID-19 Pandemic. Asian Economics Letters, $1(3), 1-5$.

Liu, L., Wang, E.-Z., ve Lee, C.-C. (2020). Impact of the COVID-19 Pandemic on the Crude Oil and Stock Markets in the US: A Time-varying Analysis. Energy Research Letters, 1(1), 1-5.

Maliszewska, M., Mattoo, A., Van Der Mensbrugghe, D., (2020). The Potential Impact of COVID-19 on GDP and Trade: A Preliminary Assessment. In:World Bank Research Working Paper (9211).

Mazumder, S. (2020). How Important is Social Trust during the COVID-19 Crisis Period? Evidence from the Fed Announcements. Journal of Behavioral And Experimental Finance, 28, 1-8.

Meng Qin, Xiuyan Liu ve Xiaoxue Zhou (2020) COVID-19 Shock and Global Value Chains: Is There a Substitute for China?, Emerging Markets Finance and Trade, 56(15), 3588-3598.

Narayan, P.K., (2020a). Oil Price News and COVID-19-Is there any Connection? Energy Res. Lett. 1(1), 1-5. 
Nguyen, D. T., Phan, D. H. B., ve Ming, T. C. (2021). An Assessment of How COVID-19 Changed the Global Equity Market. Economic Analysis and Policy, 69, 480-491.

O’Donnell, N., Shannon, D., ve Sheehan, B. (2021). Immune or at-Risk? Stock Markets and the Significance of the COVID-19 Pandemic. Journal of Behavioral and Experimental Finance, 30, 1-7.

Ortmann, R., Pelster, M., ve Wengerek, S. T. (2020). COVID-19 and Investor Behavior. Finance Research Letters, 37, 1-5.

Padhan, R., ve Prabheesh, K. P. (2021). The Economics of COVID-19 Pandemic: A Survey. Economic Analysis and Policy, 70, 220-237.

Pengcheng Song, Xuan Zhang, Yu Zhao ve Liao Xu (2020) Exogenous Shocks on the Dual-country Industrial Network: A Simulation Based on the Policies during the COVID-19 Pandemic, Emerging Markets Finance and Trade, 56(15), 3554-3561.

Prabheesh, K.P., (2013). Optimum International Reserves and Sovereign Risk: Evidence from India. J. Asian Econ. 28, 76-86.

Prabheesh, K.P. ve Vidya, C.T., (2018). Do Business Cycles, Investment-Specific Technology Shocks Matter for Stock Returns? Econ. Model. 70, 511-524.

Qin, M., Zhang, Y. C., ve Su, C. W. (2020). The Essential Role of Pandemics: A Fresh Insight into the Oil Market. Energy Research Letters, 1(1), 1-6.

Rahman, M. L., Amin, A., ve Al Mamun, M. A. (2021). The COVID-19 Outbreak and Stock Market Reactions: Evidence from Australia. Finance Research Letters, 38, 1-7.

Rizwan, M. S., Ahmad, G., ve Ashraf, D. (2020). Systemic Risk: The Impact of COVID-19. Finance Research Letters, 36, 1-7.

Sakurai, Y., ve Kurosaki, T. (2020). How has the Relationship between Oil and the US Stock Market Changed after the Covid-19 Crisis?. Finance Research Letters, 37, 1-8.

Salisu, A., Adediran, I., (2020). Uncertainty Due to İnfectious Diseases and Energy Market Volatility. Energy Res. Lett. 1 (2), 1-6.

Salisu, A. A., Akanni, L., ve Raheem, I. (2020). The COVID-19 Global Fear Index and the Predictability of Commodity Price Returns. Journal of Behavioral and Experimental Finance, 27, 1-7.

Shehzad, K., Xiaoxing, L., ve Kazouz, H. (2020). COVID-19's Disasters are Perilous than Global Financial Crisis: A Rumor or Fact?. Finance Research Letters, 36, 1-8.

Sherif, M. (2020). The Impact of Coronavirus (COVID-19) Outbreak on Faith-based Investments: An Original Analysis. Journal of Behavioral and Experimental Finance, 28, 1-9.

Sifat, I., Ghafoor, A., ve Mand, A. A. (2021). The COVID-19 Pandemic and Speculation in Energy, Precious Metals, and Agricultural Futures. Journal of Behavioral and Experimental Finance, 30, 1-8.

Smith, L. V., Tarui, N., \& Yamagata, T. (2021). Assessing the impact of COVID-19 on global fossil fuel consumption and CO2 emissions. Energy economics, 97, 1-12.

So, M. K., Chu, A. M., ve Chan, T. W. (2021). Impacts of the COVID-19 Pandemic on Financial Market Connectedness. Finance Research Letters, $38,1-8$.

Størdal, S., Lien, G., Mydland, Ø., ve Haugom, E. (2021). Effects of Strong and Weak Non-pharmaceutical Interventions on Stock Market Returns: A Comparative Analysis of Norway and Sweden during the Initial Phase of the COVID-19 Pandemic. Economic Analysis and Policy, 70, $341-350$.

Ueda, K., Valencia, F., (2014). Central Bank İndependence and Macro-Prudential Regulation. Econom. Lett. 125 (2), 327-330.

Umar, Z., ve Gubareva, M. (2020). A Time-frequency Analysis of the Impact of the Covid-19 Induced Panic on the Volatility of Currency and Cryptocurrency Markets. Journal of Behavioral and Experimental Finance, 28, 1-10.

Wang, K.-H., ve Su, C.-W. (2021). Asymmetric Link Between COVID-19 and Fossil Energy Prices. Asian Economics Letters, 1(4), 1-5.

Xu, L. (2021). Stock Return and the COVID-19 Pandemic: Evidence from Canada and the US. Finance Research Letters, 38, 1-7.

Yagi, M., ve Managi, S. (2021). Global Supply Constraints from the 2008 and COVID-19 Crises. Economic Analysis and Policy, 69, 514-528.

Yan, L., ve Qian, Y. (2020). The Impact of COVID-19 on the Chinese Stock Market: An Event Study Based on the Consumer Industry. Asian Economics Letters, 1(3), 1-4.

Yang, H., ve Deng, P. (2021). The Impact of COVID-19 and Government Intervention on Stock Markets of OECD Countries. Asian Economics Letters, 1(4), 1-6.

Yoshino, N., Taghizadeh-Hesary, F., ve Otsuka, M. (2021). Covid-19 and Optimal Portfolio Selection for Investment in Sustainable Development Goals. Finance Research Letters, 38, 1-6.

Yu, Z., Li, Y., ve Xie, X. (2021). Long-term Trade Impact of Epidemic Outbreaks: Is it V-shaped?. Economic Analysis and Policy, 71, 16-40. 
